\title{
A taxonomic study of the genus Fimbristylis Vahl (Cyperaceae) in Korea
}

\section{Jonghwan KIM and Muyeol KIM*}

\author{
Department of Biological Sciences, Chonbuk National University, Jeonju 54896, Korea
} (Received 31 October 2018; Revised 9 December 2018; Accepted 20 December 2018)

\begin{abstract}
A morphological study of Korean Fimbristylis was conducted in order to clarify the taxonomical position and scientific names among species. It was determined that the anther size and style length are important characteristics for the species-level identification of Fimbristylis. It was confirmed that Fimbristylis ovata (Burm.f.) J. Kern, which is recorded in the literature but which has no sampling specimens in Korea, grows on the grassland on Marado Island. According to this study, the genus Fimbristylis in Korea is classified into a total of 21 taxa, including four sections, nineteen species, and two varieties.
\end{abstract}

Keywords: Fimbristylis, taxonomic revision, Cyperaceae, Cyperoideae

사초과(Cyperaceae Juss.)의 하늘지기속(Fimbristylis Vahl)은 열대, 아열대 및 온대지방에 300 여 분류군이 분포 한다(Govaerts and Simpson, 2007; Govaerts, 2010).

하늘지기속은 1 년초 또는 다년초로 모여 나거나 긴 지 하경(rhizome)이 있기도 하며, 줄기는 삼각형에서 원형의 형태까지 다양하며, 포엽이 존재하고, 화서는 단생하는 단순화서이거나 복생하는 복잡한 화서이고, 소수 인편은 돌려나며 끝이 뾰족하거나 까락(own)이 달린다. 화주에 털이 있거나 없으며, 수술의 개수는 1-3개, 주두는 2-3개 로 갈라진다. 수과는 삼릉형(3-sided), 원통형이거나 양면 이 볼록한 양철형(biconvex)이다(Ohwi, 1944; Kern, 1974; Ball et al., 2002; Zhang et al., 2010).

하늘지기속은 Vahl (1805)에 의해 Scirpus속에서 암술대 기부가 부풀며 화주 가장자리에 털이 있는 특징으로 Fimbristylis acuminata Vahl을 기준종으로 하여 25분류군을 처음 기록한 후 Brown (1810)이 오스트레일리아 분류군을, Böeckeler (1871)가 71분류군을, Bentham (1878)가 Bulbostylis 를 포함하여 56분류군을, Franchet and Savatier (1877)는 일본 산 10분류군을, Ohwi (1944)는 한국, 일본, 대만산 45분류군 을, Koyama (1961) Bulbostylis를 포함하여 41분류군을, Tang and Wang (1961)은 중국산 58분류군을, Kral (1971)은 북아메 리카산 24분류군을, Kern (1974)는 말레이시아산 83분류군 을, Kuoh (1977)은 대만산 25분류군을 분류하여 지역별 분 류는 있었으나 하늘지기속 전체에 대한 분류는 없었다.

한국산 하늘지기속은 Nakai (1909)에 9분류군을 처음으 로 기록하였다. 이후 Chung et al. (1937)이 6분류군에 국명
을 최초로 기록하였다. Ohwi (1944)는 한국, 일본, 중국, 대 만 등 동북아시아에 분포하는 45 분류군을 대상으로 한국 에는 15 분류군이, Nakai (1952)는 24분류군이, Koyama (1961)는 14분류군이 분포하는 것으로 기록하였다.

한국 연구자에 의한 하늘지기속에 대한 연구는 $\mathrm{Oh}$ (1991)가 F. aestivalis (좀민하늘지기), F. autumnalis (애기하 늘지기), F. complanata for. exaltata (들하늘지기=어른지기), F. dichotoma (하늘지기), F. dichotoma subsp. longispica (큰하 늘지기), F. ferrugiena var. sieboldii (갯하늘지기), F. littoralis (바람하늘지기) 7분류군의 잎 표피형을 연구하였다.

Oh and Park (1997)이 수과의 형태로 한국산 16분류군을 2개절(sect. Mischospora, Fimbristylis)로 구분하여 수과와 잎의 표피형을 연구하고, $\mathrm{Kim}$ and $\mathrm{Kim}$ (2013)이 미기록종 인 바위하늘지기(F. hookeriana)를 보고하였고, Kim and $\operatorname{Kim}(2015 \mathrm{a}, 2015 \mathrm{~b})$ 가 물하늘지기(F. drizae)와 진도하늘지 기(F.jindoensis)를 신종기재하였다.

한국산 하늘지기속 식물의 학명과 국명에 대하여 최근 가장 보편적으로 쓰이는 Lee (1980), Lee (1996), Lee (2006) 의 문헌과 사초과만 다루어진 Oh (2000), Cho et al. (2016)의 문헌에 들하늘지기(F. pierotii)와 어른지기(F. complanata for. exaltata)의 국명과 학명이 혼용중이며, 바람하늘지기 학명이 F. miliacea와 F. littoralis로 혼용중이다. 꼴하늘지기 학명이 F. tristachya var. subbispicata와 F. subbispicata, 갯하 늘지기가 F. ferrugiena var. sieboldii와 F. sieboldii로 변종과 종으로 연구자간 각기 다르게 취급하였다. 또한 털하늘지 기 학명이 F. dichotoma for. tomentosa와 F. tomentosa, 남하

\footnotetext{
*Author for correspondence: mykim@jbnu.ac.kr
} 
Table 1. Scientific name and Korean name of Korean Fimbristylis.

\begin{tabular}{|c|c|c|c|}
\hline \multicolumn{2}{|c|}{ Present scientific name } & \multirow{2}{*}{$\begin{array}{l}\text { All scientific name used } \\
\text { Carex ovata (Burman, 1768) }\end{array}$} & Korean name \\
\hline \multirow{4}{*}{$\begin{array}{l}\text { sect. Abildgaardia } \\
\text { (쇠하늘지기절) }\end{array}$} & \multirow[t]{4}{*}{ F. ovate (쇠하늘지기) } & & - \\
\hline & & Cyperus monostachyos (L., 1771) & - \\
\hline & & F. monostachya (Hassk., 1848) & 쇠하늘지기(Lee, 1980; Oh, 2007) \\
\hline & & F. ovata (Kern, 1967) & 쇠하늘지기(Lee, 1996) \\
\hline \multirow{3}{*}{$\begin{array}{l}\text { sect. Mischospora } \\
\text { (밭하늘지기절) }\end{array}$} & \multirow{2}{*}{$\begin{array}{l}\text { F. dipsacea var. verrucifera } \\
\text { (푸른하늘지기) }\end{array}$} & Isolepis verrucifera (Max., 1859) & - \\
\hline & & F. verrucifera (Makino, 1895) & 푸른하늘지기(Lee, 1980; Lee, 1996; Oh, 2007) \\
\hline & F. stauntonii (밭하늘지기) & F. stauntonii & 밭하늘지기(Lee, 1980; Lee, 1996; Lee, 2006; Oh, 2007; Cho et al., 2016) \\
\hline \multirow[t]{7}{*}{$\begin{array}{l}\text { sect. Fimbristylis } \\
\text { (하늘지기절) }\end{array}$} & $\begin{array}{l}\text { F. squarrosa var. squarrosa } \\
\text { (민하늘지기) }\end{array}$ & F. squarrosa (Vahl, 1806) & 뚝하늘지기(Lee, 1996), 민하늘지기(Lee, 1980; Lee, 2006; Oh, 2007; Cho et al., 2016) \\
\hline & \multirow{3}{*}{$\begin{array}{l}\text { F. squarrosa var. esquarrosa } \\
\text { (암하늘지기) }\end{array}$} & Fimbristylis velata (R. Br., 1810) & - \\
\hline & & Fimbristylis makinoana (Ohwi, 1938) & - \\
\hline & & F. squarrosa var. esquarrosa & 암하늘지기(Lee, 1980; Lee, 1996; Oh, 2007; Cho et al., 2016) \\
\hline & F. aestivalis (좀민하늘지기) & F. aestivalis (Vahl, 1805) & 좀민하늘지기(Oh, 2007; Cho et al., 2016) \\
\hline & \multirow[t]{2}{*}{ F. subbispicata (꼴하늘지기) } & F. subbispicata (Nees and Meyen, 1843) & 꼴하늘지기(Lee, 1980; Lee, 1996; Lee, 2006; Cho et al., 2016) \\
\hline & & F. tristachya var. subbispicata (Koyama, 1961) & 꼴하늘지기(Oh, 2007) \\
\hline \multirow{6}{*}{$\begin{array}{l}\text { sect. Fimbristylis } \\
\text { (하늘지기절) }\end{array}$} & F. hookeriana. (바위하늘지기) & F. hookeriana & 바위하늘지기(Cho et al., 2016) \\
\hline & \multirow[t]{2}{*}{ F. sieboldii (갯하늘지기) } & F. sieboldii (Miq. ex Franch. and Sav., 1877) & 갯하늘지기(Cho et al., 2016) \\
\hline & & F. ferruginea var. sieboldii (Ohwi, 1938) & 갯하늘지기(Lee, 1980; Lee, 1996; Lee, 2006; Oh, 2007) \\
\hline & F. longispica (큰하늘지기) & F. longispica (Steud. 1855) & 큰하늘지기(Lee, 1980; Lee, 1996; Lee, 2006; Oh, 2007; Cho et al., 2016) \\
\hline & \multirow[t]{2}{*}{ F. tomentosa (털하늘지기) } & F. tomentosa (Vahl , 1806) & 털하늘지기(Cho et al., 2016) \\
\hline & & F. dichotoma for. tomentosa (Ohwi, 1965) & 털하늘지기(Lee, 1980; Oh, 2007) \\
\hline
\end{tabular}


Table 1. Continued.

\begin{tabular}{|c|c|c|c|}
\hline \multicolumn{2}{|c|}{ Present scientific name } & \multirow{2}{*}{$\begin{array}{l}\text { All scientific name used } \\
\text { Scirpus dichotomus (L., 1753) }\end{array}$} & Korean name \\
\hline $\begin{array}{l}\text { sect. Fimbristylis } \\
\text { (하늘지기절) }\end{array}$ & $\begin{array}{l}\text { F. dichotoma var. dichotoma } \\
\text { (하늘지기) }\end{array}$ & & - \\
\hline & & S. diphyllus (Retz.. 1789) & - \\
\hline & & F. diphylla (Vahl, 1805) & - \\
\hline & & F. dichotoma (Vahl, 1806) & 하늘지기(Lee, 1980; Lee, 1996; Lee, 2006; Oh, 2007; Cho et al., 2016) \\
\hline & & F. dichotoma var. tentsuki (Koyama, 1988) & - \\
\hline & $\begin{array}{l}\text { F. dichotoma var.floribunda } \\
\text { (남하늘지기) }\end{array}$ & F. diphylla var. floribunda (Miq., 1865) & - \\
\hline & & F. dichotoma for. floribunda (Ohw, 1838) & 남하늘지기(Lee, 2006; Oh, 2007) \\
\hline & & F. dichotoma var. floribunda (Koyama, 1988) & 남하늘지기(Cho et al., 2016) \\
\hline \multirow{13}{*}{$\begin{array}{l}\text { sect. Trichelostylis } \\
\text { (애기하늘지기절) }\end{array}$} & F. sericea (털잎하늘지기) & F. sericea (R. Br., 1810) & 털잎하늘지기(Lee, 1996; Oh, 2007; Cho et al., 2016), 털하늘지기(Lee, 1996) \\
\hline & & Scirpus sericeus (Poir., 1817) & - \\
\hline & F. littoralis (바람하늘지기) & Scirpus miliaceus (L., 1759) & - \\
\hline & & F. miliacea (Vahl, 1805) & 바람하늘지기(Lee, 1980; Lee, 1996; Lee, 2006; Oh, 2007) \\
\hline & F. pierotii (들하늘지기) & F. pierotii & 들하늘지기(Lee, 1980; Lee, 1996; Oh, 2007; Cho et al., 2016) \\
\hline & F. jindoensis (진도하늘지기) & F. jindoensis (J. Kim \& M. Kim, 2015A) & - \\
\hline & F. diphylloides (검정하늘지기) & F. diphylloides (Makino, 1925) & 검정하늘지기(Lee, 1980; Lee, 1996; Oh, 2007; Cho et al., 2016) \\
\hline & F. drizae (물하늘지기) & F. drizae (J. Kim \& M. Kim, 2015B) & 물하늘지기(Cho et al., 2016) \\
\hline & $\begin{array}{l}\text { F. complanata var. exaltata } \\
\text { (어른지기) }\end{array}$ & F. complanata (Link, 1827) & 어른지기(Lee, 1980; Lee, 1996), 들하늘지기(Lee, 2006) \\
\hline & & F. complanata for. exaltata (Koyama, 1959) & 들하늘지기(Oh, 2007) \\
\hline & & $\begin{array}{l}\text { F. complanata var. exaltata (Tang ex Zhang and Koyama, } \\
\text { 2010) }\end{array}$ & 어른지기(Cho et al., 2016) \\
\hline & F. autumnalis (애기하늘지기) & Scirpus autumnalis (L., 1771) & - \\
\hline & & F. autumnalis (Roem. and Schult., 1817) & 애기하늘지기(Lee, 1980; Lee, 1996; Lee, 2006; Oh, 2007; Cho et al., 2016) \\
\hline
\end{tabular}


늘지기 학명이 F. dichotoma for. floribunda와 F. dichotoma var. floribunda로 종, 변종, 품종으로 달리 취급한 견해가 있었다(Table 1).

이와 같이 한국에 분포하는 하늘지기속은 연구자들 간 에 국명과 학명에 대한 혼란이 존재하고 그동안 종합적이 고 체계적인 정리가 수행되지 않아, 외부형태학적 측면에 서 종의 한계를 재검토하고, 학명과 국명에 대해 종합적 으로 재정리하여 하늘지기속에 대한 분류 및 계통학적 연 구를 수행하는데 기초자료를 제공하고자 하였다.

\section{재료 및 방법}

\section{재료}

본 연구에 사용된 재료는 2012년부터 2017년까지 직접 채집한 국내표본 835 점과 해외표본 157 점, 국립수목원 산 림생물표본관 $(\mathrm{KH})$ 에 소장된 1,420 점, 국립생물자원관 $(\mathrm{KB})$ 에 소장된 1,042 점 등 총 3,454점의 표본을 사용하였 다. 본 연구 기간 중 직접 채집한 개체는 Kern (1974), Lee (1980), Zhang et al. (2010), Cho et al. (2016) 등의 문헌을 이 용하여 동정하였고, 실온에서 건조 후 석엽 표본으로 제작 하여 전북대학교 생명과학과 표본관(JNU)에 보관하였다.

정량형질 측정을 위해 분류군별로 성숙된 것에서 10 개

Table 2. List of quantitative characters measured for variation analyses of Fimbristylis.

\begin{tabular}{lc}
\hline \hline No & Quantitative characters \\
\hline 1 & Plant length \\
2 & Culm length \\
3 & Culm width \\
4 & Leaf length \\
5 & Leaf width \\
6 & Bract length \\
7 & Bract width \\
8 & Inflorescence length \\
9 & Inflorescence width \\
10 & Branch in Inflorescence length \\
11 & Spikelet length \\
12 & Spikelet width \\
13 & Scale length \\
14 & Scale width \\
15 & Achene length \\
16 & Achene Width \\
17 & Style length \\
18 & Stigma length \\
19 & Anther length \\
\hline
\end{tabular}

체씩(쇠하늘지기 3 개체) 선별하여 측정하였다. 측정한 표 본은 Appendix 1에 정리하였다.

국내 문헌상 기록은 있으나 채집 및 관찰 표본에서 확인 되지 않은 바다지기(Fimbristylis cymosa R. Brown)와 제주 하늘지기(F. schoenoides (Retz.) Vahl)는 본 연구에서 제외 하여 총 21 분류군에 대하여 연구를 진행하였다.

하늘지기속 식물의 외부형태에 관한 용어는 Lee (1980), Oh (2000), Cho et al. (2016) 등이 사용한 용어 중 가장 적절 한 용어를 골라 사용하였다.

\section{방법}

외부 형태학적 정량형질은 전자식 버지니어캘리퍼스 (CD-15CPX, Kawasaki, Mitutoyo, Japan)와 해부현미경 (Nikon SM-10, Tokyo, Japan)으로 관찰하였고, 사진 촬영시 전초, 화서 등의 촬영은 Nikon D80 및 D7100 디지털카메 라에 $60 \mathrm{~mm}$ 마크로렌즈를 장착하여 촬영하였고, 수과, 암 술 등 해부학적 사진은 $100 \mathrm{~mm}$ 마크로렌즈에 4 배 접사용 필터를 사용하였으며, 크기를 쉽게 식별할 수 있도록 사 진 촬영시 $1 \mathrm{~mm}$ 단위의 눈금이 그려진 모눈종이를 바탕 에 깔고 촬영하였다.

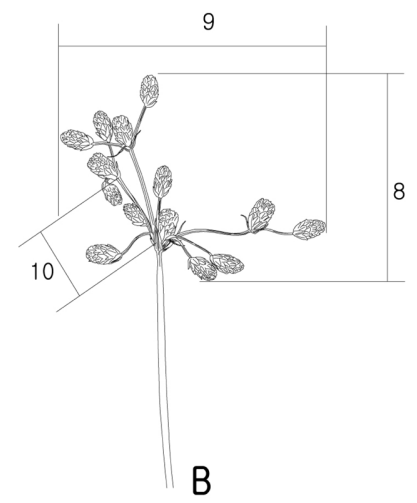

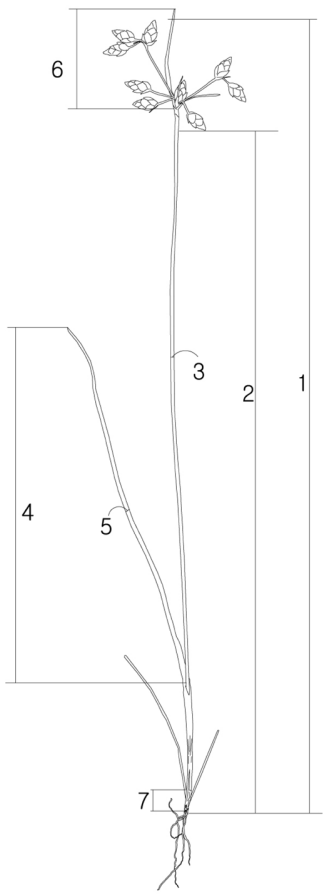

A
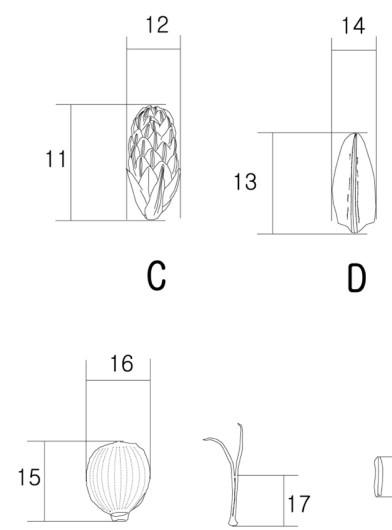

E

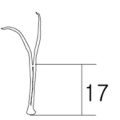

$\mathrm{F}$
Fig. 1. Diagram of morphological characteristics of Korean Fimbristylis. A. Habit. B. Inflorescences. C. Spikelet. D. Scale. E. Achene. F. Style. G. Anther. 
Table 3. Qualitative characters of Korean Fimbristylis.

\begin{tabular}{|c|c|c|c|c|c|c|c|}
\hline Taxa & Habit & Rhizome & Plant & $\begin{array}{c}\text { Basal } \\
\text { leaf }\end{array}$ & Ligule & $\begin{array}{c}\text { Culm } \\
\text { cross-section shape }\end{array}$ & $\begin{array}{l}\text { Spikelet } \\
\text { shape }\end{array}$ \\
\hline F. ovata & Perennial & Short & Glabrous & Long & Absent & 3-5 Furrowed oval & Ovoid \\
\hline F. dipsacea var. verrucifera & Annual & Absent & Glabrous & Bladeless & Absent & 3-5 Furrowed oval & Oblong-ovoid \\
\hline F. stauntonii & Annual & Absent & Glabrous & Long & Ciliate & Circle & Ovoid \\
\hline F. squarrosa & Annual & Absent & Pubescent & Bladeless & Ciliate & 2-3 Furrowed oval & Oblong-ovoid \\
\hline F. squarrosa var. esquarrosa & Annual & Absent & Pubescent & Bladeless & Ciliate & 2-3 Furrowed oval & Oblong-ovoid \\
\hline F. sericea & Perennial & Long & Pubescent & Long & Absent & Circle & Oblong-ovoid \\
\hline F. aestivalis & Annual & Absent & Glabrous & Long & Absent & 2-3 Furrowed oval & Ovoid \\
\hline F. subbispicata & Perennial & Short & Glabrous & Long & Ciliate & Circle & Oblong-ovoid \\
\hline F. hookeriana. & Annual & Absent & Glabrous & Long & Absent & Circle & Narrowly ovoid \\
\hline F. sieboldii & Perennial & Short & Glabrous & Bladeless & Ciliate & Circle & Oblong-ovoid \\
\hline F. longispica & Perennial & Short & Glabrous & Long & Absent & Circle & Oblong-ovoid \\
\hline F. tomentosa & Annual & Absent & $\begin{array}{l}\text { Pubescent to sub } \\
\text { glabrous }\end{array}$ & Long & Ciliate & 3-4 Furrowed oval & Ovoid \\
\hline F. dichotoma var. dichotoma & $\begin{array}{l}\text { Annual or } \\
\text { perennial }\end{array}$ & Absent & $\begin{array}{l}\text { Pubescent to sub } \\
\text { glabrous }\end{array}$ & Long & Ciliate & 3-4 Furrowed oval & Ovoid \\
\hline F. dichotoma var. floribunda & Perennial & Short & Glabrous & Long & Ciliate & Circle & Ovoid \\
\hline F. littoralis & Annual & Absent & Glabrous & Bladeless & Absent & $\begin{array}{l}\text { Slightly compress } 4 \\
\text { angled }\end{array}$ & $\begin{array}{c}\text { Globose to } \\
\text { ovoid }\end{array}$ \\
\hline F. pierotii & Perennial & Long & Glabrous & Long & Absent & 5-6 Furrowed circle & Oblong \\
\hline F. jindoensis & Perennial & Long & Glabrous & Long & Ciliate & Oval & Oblong-ovoid \\
\hline F. diphylloides & Perennial & Short & Glabrous & Bladeless & Absent & 5 Angled & Ovoid \\
\hline F. drizana & Perennial & Short & Glabrous & Bladeless & Absent & 5 Angled & Oval to ovoid \\
\hline F. exaltata & Perennial & Short & Glabrous & Long & Ciliate & 2 Furrowed oval & Oblong \\
\hline F. autumnalis & Annual & Absent & Glabrous & Long & Ciliate & 2-3 Furrowed oval & Oblong \\
\hline
\end{tabular}

Table 3. Continued.

\begin{tabular}{|c|c|c|c|c|c|c|}
\hline \multirow{2}{*}{ Taxa } & \multicolumn{4}{|c|}{$\overline{\text { Scale }}$} & \multicolumn{2}{|l|}{ Style } \\
\hline & Hair & Shape & Apex & Color & Hair & Shape \\
\hline$\overline{F . \text { ovata }}$ & Glabrous & Broadly-ovate & Mucronate & Yellowish-green & Ciliate & Flat \\
\hline F. dipsacea var. verrucifera & Glabrous & Lanceolate-oblong & Awned & Straw-yellow & Glabrous & Flat \\
\hline F. stauntonii & Glabrous & Lanceolate-oblong & Awned & Straw-yellow & Glabrous & Flat \\
\hline F. squarrosa & Glabrous & Oblong-ovate & Awned & Straw-yellow & Base and apically ciliate & Compressed \\
\hline F. squarrosa var. esquarrosa & Glabrous & Oblong-ovate & Acut & Straw-yellow & Base and apically ciliate & Compressed \\
\hline F. sericea & Pubescent & Ovate & Mucronate & Straw-yellow & Base ciliate & Slightly compress \\
\hline F. aestivalis & Glabrous & Oblong-ovate & Mucronate & Brown & Glabrous & Flat \\
\hline F. subbispicata & Glabrous & Ovate & Mucronate & Brown & Apically ciliate & Flat \\
\hline F. hookeriana. & Glabrous & Ovate & Mucronate & Brown & Apically ciliate & Flat \\
\hline F. sieboldii & Pubescent & Ovate & Mucronate & Brown & Apically ciliate & Flat \\
\hline F. longispica & Glabrous & Ovate & Mucronate & Straw-yellow & Apically ciliate & Flat \\
\hline F. tomentosa & Glabrous & Ovate & Mucronate & Brown & Apically ciliate & Flat \\
\hline F. dichotoma var. dichotoma & Glabrous & Ovate & Mucronate & Brown & Apically ciliate & Flat \\
\hline F. dichotoma var. floribunda & Glabrous & Ovate & Mucronate & Brown & Apically ciliate & Flat \\
\hline F. littoralis & Glabrous & Ovate & Obtuse & Chestnut-brown & Glabrous & 3 -sided \\
\hline F. pierotii & Glabrous & Lanceolate-ovoid & Subacut & Brown & Glabrous & 3-sided \\
\hline F. jindoensis & Glabrous & Lanceolate-ovoid & Acut & Brown & Glabrous & 3 -sided \\
\hline F. diphylloides & Glabrous & Ovate & Obtuse & Blackish brown & Glabrous & 3 -sided \\
\hline F. drizana & Glabrous & Ovate & Obtuse & Straw-yellow & Glabrous & 3 -sided \\
\hline F. exaltata & Glabrous & Lanceolate-ovoid & Acut & Brown & Glabrous & 3 -sided \\
\hline F. autumnalis & Glabrous & Lanceolate-ovoid & Acut & Pale brown & Glabrous & 3 -sided \\
\hline
\end{tabular}


Table 3. Continued.

\begin{tabular}{|c|c|c|c|c|c|c|}
\hline \multirow{2}{*}{ Taxa } & \multirow{2}{*}{$\begin{array}{l}\text { Stigma } \\
\text { number }\end{array}$} & \multirow{2}{*}{$\begin{array}{l}\text { Anther } \\
\text { number }\end{array}$} & \multicolumn{3}{|c|}{ Achene } & \multirow{2}{*}{$\begin{array}{c}\begin{array}{c}\text { Fruiting } \\
\text { season }\end{array}\end{array}$} \\
\hline & & & Shape & Color & Surface & \\
\hline$\overline{F . ~ o v a t a}$ & 3 & 3 & Obtuse 3-sided & Gray brown & Verruculose & Jul to Sep \\
\hline F. dipsacea var. verrucifera & 2 & 1 & Oblong & Brown & $\begin{array}{l}\text { clavate } \\
\text { Glandular }\end{array}$ & Jun to Oct \\
\hline F. stauntonii & 2 or 3 & 1 or 2 & Oblong & Yellowish white & Reticulation & Aug to Oct \\
\hline F. squarrosa & 2 & 1 & Biconvex & Yellowish white & Glabrous & Jun to Oct \\
\hline F. squarrosa var. esquarrosa & 2 & 1 & Biconvex & Yellowish white & Glabrous & Jun to Oct \\
\hline F. sericea & 2 & 2 or 3 & Obtuse 3-sided & Blackish purple & Glabrous & Aug to Oct \\
\hline F. aestivalis & 2 & 1 & Biconvex & Brown & Glabrous & Jun to Oct \\
\hline F. subbispicata & 2 & 3 & Biconvex & Brown & Reticulation & Aug. to Oct \\
\hline F. hookeriana. & 2 & 2 or 3 & Biconvex & Yellowish white & Reticulation & Aug to Nov \\
\hline F. sieboldii & 2 & 3 & Biconvex & Blackish purple & Glabrous & Jul to Oct \\
\hline F. longispica & 2 & 3 & Biconvex & Brown & Reticulation & Jul to Sep \\
\hline F. tomentosa & 2 & 2 & Biconvex & White & Reticulation & Aug to Oct \\
\hline F. dichotoma var. dichotoma & 2 & 2 & Biconvex & White & Reticulation & Aug to Oct \\
\hline F. dichotoma var. floribunda & 2 & 2 & Biconvex & White & Reticulation & Aug to Oct \\
\hline F. littoralis & 3 & 3 & Obtuse 3-sided & Straw-yellow & Verruculose & Aug to Oct \\
\hline F. pierotii & 3 & 3 & Obtuse 3-sided & Brown or brownish yellow & Verruculose & Jun to Jul \\
\hline F. jindoensis & 3 & 3 & Obtuse 3-sided & Yellowish brown & Verruculose & Jul to Aug \\
\hline F. diphylloides & 2 or 3 & 2 & Obtuse 3 -sided or biconvex & Yellowish brown & Verruculose & Aug to Oct \\
\hline F. drizana & 2 & 1 (rare 2) & Obtuse 3-sided or biconvex & Yellowish brown & Verruculose & Aug to Oct \\
\hline F. exaltata & 3 & 3 & 3 -sided & Yellowish white & Verruculose & Aug to Oct \\
\hline F. autumnalis & 3 & 1 or 2 & 3-sided & Yellowish white & $\begin{array}{l}\text { Glabrous to } \\
\text { verruculose }\end{array}$ & Aug to Oct \\
\hline
\end{tabular}

Table 4. Quantitative characters of Korean Fimbristylis.

\begin{tabular}{|c|c|c|c|c|c|c|}
\hline \multirow{2}{*}{ Taxa } & \multirow{2}{*}{$\begin{array}{c}\text { Plant } \\
\text { Length }(\mathrm{cm})\end{array}$} & \multicolumn{2}{|c|}{ Culm } & \multicolumn{2}{|c|}{ Leaf } & \multirow{2}{*}{$\begin{array}{l}\text { Bladeless sheath } \\
\text { length }(\mathrm{cm})\end{array}$} \\
\hline & & Length $(\mathrm{cm})$ & Width (mm) & Length $(\mathrm{cm})$ & Width (mm) & \\
\hline$\overline{\text { F. ovata }}$ & $7.7(14.2) 19.8$ & $7.1(13.4) 19.1$ & $0.5(0.6) 0.9$ & $4.4(9.6) 17.5$ & $0.8(1.2) 1.9$ & Absent \\
\hline F. dipsacea var. verrucifera & $2.1(8.6) 14.1$ & $0.6(7.6) 12.6$ & $0.2(0.3) 0.4$ & $0.3(1.5) 2.8$ & $0.2(0.2) 0.3$ & $2.2(3.6) 4.9$ \\
\hline F. stauntonii & $7.7(31.6) 46.0$ & $4.0(23.4) 36.7$ & $0.6(1.3) 2.0$ & $3.0(14.2) 28.3$ & $1.1(2.1) 3.4$ & Absent \\
\hline F. squarrosa & $5.8(17.2) 23.4$ & $2.8(14.1) 20.3$ & $0.3(0.5) 0.7$ & $0.4(2.5) 6.2$ & $0.2(0.3) 0.5$ & $0.6(1.0) 4.1$ \\
\hline F. squarrosa var. esquarrosa & $7.8(13.7) 25.4$ & $3.8(9.6) 21.6$ & $0.4(0.5) 0.6$ & $0.6(2.1) 6.2$ & $0.4(0.5) 0.6$ & $0.7(0.8) 0.9$ \\
\hline F. sericea & $13.5(20.3) 25.2$ & $12.0(18.5) 23.7$ & $0.8(1.3) 1.7$ & $2.7(6.4) 11.5$ & $1.0(1.8) 2.5$ & Absent \\
\hline F. aestivalis & $7.6(12.8) 18.0$ & $2.4(9.8) 14.6$ & $0.2(0.4) 0.6$ & $0.7(3.2) 6.9$ & $0.2(0.4) 0.6$ & Absent \\
\hline F. subbispicata & $21.2(34.7) 51.6$ & $16.6(33.3) 50.2$ & $0.6(0.7) 1.0$ & $2.3(16.4) 30.8$ & $0.6(0.8) 1.1$ & Absent \\
\hline F. hookeriana. & $6.9(14.9) 19.4$ & $4.1(13.0) 17.2$ & $0.6(0.8) 1.0$ & $4.1(13.1) 19.2$ & $1.0(1.7) 2.5$ & Absent \\
\hline F. sieboldii & $9.7(28.7) 44.9$ & $7.2(25.4) 40.2$ & $0.3(0.6) 1.1$ & $3.6(8.3) 15.5$ & $0.3(0.6) 0.9$ & Absent \\
\hline F. longispica & $43.5(56.9) 68.8$ & $38.0(51.7) 62.0$ & $1.7(2.1) 2.5$ & $19.7(26.3) 36.5$ & $1.9(2.5) 3.2$ & Absent \\
\hline F. tomentosa & $12.2(29.1) 43.2$ & $9.8(25.6) 39.5$ & $0.5(0.8) 1.2$ & $4.9(15.7) 30.9$ & $0.6(1.3) 2.1$ & Absent \\
\hline F. dichotoma var. dichotoma & $10.6(22.0) 40.6$ & $4.8(18.5) 36.0$ & $0.2(0.7) 1.1$ & $2.6(11.1) 21.6$ & $0.4(1.7) 2.2$ & Absent \\
\hline F. dichotoma var. floribunda & $13.8(40.2) 60.0$ & $9.3(34.9) 56.7$ & $0.6(0.9) 1.2$ & $3.6(26.2) 45.9$ & $1.1(1.8) 2.3$ & Absent \\
\hline F. littoralis & $14.2(29.7) 46.7$ & $11.0(24.6) 44.0$ & $0.8(1.2) 1.8$ & $8.1(23.0) 39.0$ & $1.0(1.4) 1.9$ & $1.3(5.1) 10.4$ \\
\hline F. pierotii & $9.1(26.3) 48.1$ & $6.1(25.1) 47.5$ & $0.7(0.9) 1.1$ & $2.0(9.0) 27.0$ & $0.9(1.3) 1.7$ & $0.4(1.6) 5.0$ \\
\hline F. jindoensis & $59.2(83.3) 95.5$ & $57.0(77.5) 88.0$ & $1.7(2.4) 3.5$ & $7.5(29.9) 51.0$ & $1.7(2.4) 3.0$ & Absent \\
\hline F. diphylloides & $11.3(28.6) 52.4$ & $9.1(25.0) 52.4$ & $0.5(0.8) 1.0$ & $9.1(22.3) 50.9$ & $0.7(1.4) 2.2$ & $1.1(3.7) 8.2$ \\
\hline F. drizana & $5.5(19.9) 37.1$ & $3.2(16.7) 31.3$ & $0.7(0.9) 1.1$ & $6.9(19.6) 35.9$ & $0.9(1.6) 2.4$ & $1.0(2.6) 4.6$ \\
\hline F. exaltata & $12.9(30.9) 48.1$ & 11.5 (27.4) 40.0 & $0.8(1.0) 1.3$ & $5.5(15.2) 33.0$ & $1.1(1.7) 2.6$ & Absent \\
\hline F. autumnalis & $10.7(26.8) 45.9$ & $4.2(22.2) 39.4$ & $0.6(1.0) 1.2$ & 2.5 (11.7) 22.8 & $0.8(1.7) 2.7$ & Absent \\
\hline
\end{tabular}


Table 4. Continued.

\begin{tabular}{|c|c|c|c|c|c|c|}
\hline \multirow{2}{*}{ Taxa } & \multirow{2}{*}{$\begin{array}{c}\text { Bract } \\
\text { Length }(\mathrm{cm})\end{array}$} & \multicolumn{3}{|c|}{ Inflorescence } & \multicolumn{2}{|c|}{ Spikelet } \\
\hline & & Length $(\mathrm{cm})$ & Width $(\mathrm{cm})$ & Branch (mm) & Length (mm) & Width (mm) \\
\hline F. ovata & $0.0(6.8) 8.5$ & Absent & Absent & Absent & $6.0(7.1) 9.5$ & $3.1(3.5) 3.8$ \\
\hline F. dipsacea var. verrucifera & $0 . .2(0.4) 0.5$ & $1.1(1.6) 2.3$ & $1.5(2.1) 2.7$ & $2.7(5.4) 11.5$ & $2.9(5.0) 7.8$ & $1.8(2.2) 2.5$ \\
\hline F. stauntonii & $3.3(6.9) 11.8$ & $3.5(8.2) 11.9$ & $1.5(7.3) 13.2$ & $2.5(30.7) 78.5$ & $3.2(4.1) 5.3$ & $1.4(1.7) 2.0$ \\
\hline F. squarrosa & $0.5(3.0) 4.2$ & $1.3(3.1) 5.2$ & $1.4(5.0) 7.4$ & $8.7(18.9) 35.2$ & $3.5(5.9) 9.1$ & $1.2(1.6) 1.9$ \\
\hline F. squarrosa var. esquarrosa & $0.3(2.3) 5.8$ & $3.2(4.1) 5.2$ & $1.9(4.9) 8.0$ & $10.0(21.3) 36.0$ & $3.5(6.1) 9.8$ & $1.3(1.5) 1.8$ \\
\hline F. sericea & $0.9(1.3) 2.1$ & $1.1(1.8) 2.6$ & $1.3(2.2) 2.9$ & $3.4(7.5) 11.0$ & $6.7(9.4) 13.5$ & $3.1(3.4) 3.9$ \\
\hline F. aestivalis & $0.2(1.6) 3.5$ & $1.9(3.5) 5.2$ & $1.8(3.1) 4.3$ & $5.0(17.3) 29.0$ & $2.5(3.9) 5.3$ & $1.1(1.4) 1.9$ \\
\hline F. subbispicata & $0.8(2.0) 4.2$ & Absent & Absent & Absent & $11.0(14.1) 20.0$ & $3.8(4.4) 5.0$ \\
\hline F. hookeriana. & $5.1(6.5) 8.1$ & 1.7 (1.9) 2.8 & $1.8(2.4) 3.3$ & $2.5(12.3) 19.9$ & $6.5(10.7) 16.9$ & $1.6(1.7) 1.8$ \\
\hline F. sieboldii & $3.1(3.2) 3.2$ & $2.5(3.3) 4.9$ & $1.3(2.3) 3.2$ & $9.0(16.4) 34.0$ & $8.1(11.0) 20.1$ & $2.2(2.9) 3.1$ \\
\hline F. longispica & $1.3(9.2) 12.9$ & $3.2(5.2) 6.8$ & $2.7(5.0) 6.9$ & $8.7(19.7) 31.7$ & $7.1(12.3) 23.0$ & $2.8(3.2) 4.1$ \\
\hline F. tomentosa & $1.1(5.1) 10.2$ & $1.5(5.1) 10.2$ & $1.1(3.8) 7.6$ & $4.5(16.9) 46.0$ & $3.6(5.5) 7.5$ & $1.9(2.4) 2.6$ \\
\hline F. dichotoma var dichotoma & $0.6(1.2) 3.2$ & $1.2(3.6) 5.8$ & $1.2(3.4) 5.6$ & $2.0(7.2) 17.5$ & $4.2(6.6) 8.1$ & $2.1(2.5) 3.0$ \\
\hline F. dichotoma var. floribunda & $0.6(5.0) 7.2$ & $0.7(3.0) 6.6$ & $0.9(2.5) 4.5$ & $3.0(10.9) 25.0$ & $5.2(8.1) 13.2$ & $2.3(2.9) 3.7$ \\
\hline F. littoralis & $1.3(2.0) 2.4$ & $3.2(5.3) 7.2$ & $2.3(5.0) 7.8$ & $3.1(17.7) 42.3$ & $2.0(2.7) 3.5$ & $1.6(1.9) 2.3$ \\
\hline F. pierotii & $0.6(0.9) 1.3$ & 0.9 (1.6) 3.0 & $0.3(0.8) 1.8$ & $4.0(8.9) 18.0$ & $4.8(6.4) 13.2$ & $1.7(2.2) 3.2$ \\
\hline F. jindoensis & $2.2(5.1) 10.2$ & $2.2(5.8) 8.0$ & $1.1(2.8) 4.5$ & $5.0(27.0) 57.0$ & $4.2(5.8) 7.2$ & $1.2(1.5) 1.7$ \\
\hline F. diphylloides & $0.7(1.0) 1.7$ & $1.8(3.2) 5.6$ & $1.1(2.5) 4.8$ & $4.0(22.5) 38.0$ & $4.2(5.0) 6.2$ & $1.8(2.1) 2.5$ \\
\hline F. drizana & $0.7(0.9) 0.9$ & $1.2(3.2) 5.8$ & $1.2(3.2) 5.6$ & 3.0 (13.4) 25.0 & 2.9 (4.8) 5.8 & $1.7(2.3) 2.9$ \\
\hline F. exaltata & $1.2(2.8) 8.3$ & $1.4(3.7) 8.1$ & $1.2(3.7) 6.5$ & $1.6(12.9) 41.0$ & $4.4(5.8) 9.6$ & $1.2(1.4) 1.6$ \\
\hline F. autumnalis & 1.8 (4.3) 7.3 & $2.0(4.8) 6.5$ & $2.0(3.8) 8.8$ & $4.1(17.4) 30.0$ & $3.8(4.8) 6.5$ & 1.0 (1.6) 2.2 \\
\hline
\end{tabular}

Table 4. Continued.

\begin{tabular}{|c|c|c|c|c|c|c|}
\hline \multirow{2}{*}{ Taxa } & \multicolumn{2}{|c|}{ Scale } & \multirow{2}{*}{$\begin{array}{c}\text { Anther } \\
\text { length }(\mathrm{mm})\end{array}$} & \multirow{2}{*}{$\begin{array}{c}\text { Style } \\
-\quad \text { length }(\mathrm{mm})\end{array}$} & \multicolumn{2}{|c|}{ Achene } \\
\hline & Length (mm) & Width (mm) & & & Length (mm) & Width (mm) \\
\hline F. ovata & $3.7(4.4) 5.5$ & $3.3(4.0) 4.4$ & $1.6(1.9) 2.1$ & $1.7(1.9) 2.2$ & $2.1(2.3) 2.4$ & $1.3(1.4) 1.5$ \\
\hline F. dipsacea var. verrucifera & $1.1(1.3) 1.5$ & $0.2(0.3) 0.4$ & $0.2(0.3) 0.3$ & $0.4(0.5) 0.6$ & $0.4(0.5) 0.6$ & $0.1(0.1) 0.2$ \\
\hline F. stauntonii & $1.6(1.9) 2.2$ & $0.2(0.3) 0.4$ & $0.2(0.3) 0.3$ & $0.6(0.7) 0.7$ & $0.7(0.7) 0.7$ & $0.3(0.3) 0.3$ \\
\hline F. squarrosa & $1.1(1.2) 1.3$ & $0.5(0.6) 0.6$ & $0.2(0.3) 0.3$ & $0.6(0.6) 0.7$ & $0.5(0.6) 0.7$ & $0.4(0.5) 0.6$ \\
\hline F. squarrosa var. esquarrosa & $1.5(1.7) 1.9$ & $0.5(0.6) 0.7$ & $0.2(0.3) 0.3$ & $0.6(0.7) 0.9$ & $0.5(0.6) 0.7$ & $0.4(0.4) 0.5$ \\
\hline F. sericea & $2.8(3.5) 3.7$ & $2.1(2.5) 2.9$ & $1.5(1.7) 1.8$ & $1.4(1.7) 1.8$ & $1.4(1.5) 1.5$ & $1.1(1.3) 1.4$ \\
\hline F. aestivalis & $0.9(1.1) 1.3$ & $0.4(0.5) 0.6$ & $0.2(0.3) 0.3$ & $0.4(0.5) 0.6$ & $0.4(0.5) 0.6$ & $0.3(0.3) 0.3$ \\
\hline F. subbispicata & $5.1(5.8) 6.5$ & $2.1(2.6) 2.8$ & $1.3(1.7) 2.2$ & $2.6(2.9) 3.4$ & $1.7(1.9) 2.1$ & $1.0(1.1) 1.3$ \\
\hline F. hookeriana. & $3.7(4.0) 4.5$ & $1.6(1.7) 1.8$ & $0.8(1.0) 1.1$ & $1.9(2.3) 2.6$ & $1.0(1.3) 1.4$ & $0.8(0.9) 1.0$ \\
\hline F. sieboldii & $3.0(3.2) 3.5$ & $1.6(1.7) 2.1$ & $0.8(0.8) 0.9$ & $1.0(1.4) 1.7$ & $1.0(1.2) 1.3$ & $0.8(1.0) 1.1$ \\
\hline F. longispica & $2.8(3.4) 4.1$ & $2.0(2.2) 2.5$ & $1.0(1.2) 1.4$ & $1.1(1.5) 2.2$ & $1.3(1.4) 1.5$ & $1.1(1.2) 1.4$ \\
\hline F. tomentosa & $2.1(2.3) 2.7$ & $1.5(1.6) 1.8$ & $0.4(0.5) 0.6$ & $0.8(1.0) 1.2$ & $1.1(1.3) 1.4$ & $0.8(1.0) 1.2$ \\
\hline F. dichotoma var. dichotoma & $2.1(2.5) 2.9$ & $1.6(1.3) 2.1$ & $0.6(1.0) 1.5$ & $0.8(1.0) 1.2$ & $1.2(1.4) 1.6$ & $0.9(1.1) 1.2$ \\
\hline F. dichotoma var. floribunda & $2.5(2.9) 3.2$ & $1.6(1.8) 2.1$ & $0.8(1.2) 1.5$ & $1.2(1.5) 1.6$ & $1.1(1.2) 1.4$ & $0.7(1.0) 1.1$ \\
\hline F. littoralis & $1.0(1.1) 1.3$ & $0.6(0.6) 0.8$ & $0.3(0.4) 0.5$ & $0.4(0.5) 0.6$ & $0.6(0.6) 0.7$ & $0.3(0.4) 0.5$ \\
\hline F. pierotii & $4.0(4.5) 5.1$ & $2.5(2.7) 3.0$ & $1.9(2.1) 2.3$ & $2.5(2.8) 3.1$ & $1.2(1.3) 1.4$ & $0.9(1.0) 1.1$ \\
\hline F. jindoensis & $2.8(3.1) 3.6$ & $1.6(2.1) 2.5$ & $1.1(1.4) 1.5$ & $1.6(1.7) 1.8$ & $0.7(0.8) 0.9$ & $0.5(0.6) 0.6$ \\
\hline F. diphylloides & $1.4(1.6) 1.8$ & $0.9(0.9) 1.1$ & $0.5(0.5) 0.6$ & $0.6(0.7) 0.8$ & $0.7(0.8) 0.8$ & $0.5(0.6) 0.6$ \\
\hline F. drizana & $1.7(1.9) 2.2$ & $0.9(1.1) 1.2$ & $0.5(0.5) 0.7$ & $0.8(0.9) 1.2$ & $0.6(0.8) 0.9$ & $0.5(0.5) 0.6$ \\
\hline F. exaltata & $2.2(2.5) 3.2$ & $1.1(1.3) 1.4$ & $1.2(1.4) 1.6$ & 1.4 (1.6) 1.7 & $0.7(0.8) 0.8$ & $0.4(0.5) 0.5$ \\
\hline F. autumnalis & $1.6(1.8) 2.1$ & $1.0(1.1) 1.1$ & $0.3(0.4) 0.5$ & $0.7(0.8) 0.9$ & $0.6(0.7) 0.8$ & $0.4(0.5) 0.6$ \\
\hline
\end{tabular}

* Minimum (mean) maximum. 
식물체의 크기, 줄기의 높이와 너비, 잎의 길이와 너비, 화서의 길이와 너비, 소수의 길이와 너비, 인편의 길이와 너비, 약의 길이(anther size), 화주의 길이, 수과의 길이와 너비 등 정량형질 18 개와 생활형(life form), 식물체의 털 유무, 지하 근경의 발달 유무, 화경 기부의 초상엽 (bladeless sheath) 유무, 엽설(ligule)의 유무, 줄기 단면의 모 양, 소수의 모양, 화주의 모양과 털 유무, 암술머리의 갈라 진 개수, 인편의 모양과 색, 수과의 모양과 표면 무늬 및 돌 기(verruculose) 유무 등 정성형질 19개를 관찰(Table 2)하 여 Tables 3, 4에 정리하였고, 측정기준 모식도를 제시하였 다(Fig. 1).

\section{결 과}

\section{생태학적 연구}

1. 분포지

하늘지기속의 분포지는 경남과 전남 이남으로 한반도 남부가 북한계인 남부형, 충남과 대구 등 한반도 중남부 가 북한계인 중남부형, 한국 전역에 분포하는 전국형 등 세 개의 지역으로 구분되었다

1) 남부형

남하늘지기, 들하늘지기, 진도하늘지기, 털잎하늘지기, 털하늘지기, 쇠하늘지기이다. 이 중 진도하늘지기는 전남 진도군에서만 관찰되고, 쇠하늘지기는 제주도에서만 관 찰되며, 전남, 경남 도서지방과 제주도에서는 남하늘지기, 털잎하늘지기, 털하늘지기가 관찰되며, 전남, 경남 이남 에서 들하늘지기가 관찰된다.

2) 중남부형

물하늘지기, 검정하늘지기, 푸른하늘지기, 바위하늘지 기가 확인되었다.

3) 전국형

갯하늘지기, 큰하늘지기, 민하늘지기, 암하늘지기, 좀 민하늘지기, 바람하늘지기, 밭하늘지기, 하늘지기, 애기 하늘지기, 어른지기, 꼴하늘지기로 확인되었다.

\section{2. 생육지}

생육지는 바닷가형, 건조한 지역, 저수지형, 산지습지 형, 경작지형, 기타 지역 등 6개 생육형으로 구분되었다.

1) 바닷가형

(1) 염습지 및 기수역 생육형: 갯하늘지기, 큰하늘지기

(2) 사구 생육형: 털잎하늘지기

(3) 염전 주변 생육형: 갯하늘지기

(4) 바닷가 초지 생육형: 남하늘지기, 쇠하늘지기

2) 건조한 초지형

(1) 묘지 및 초지 생육형: 들하늘지기

(2) 바위 생육형: 바위하늘지기

3) 저수지형

(1) 만수위선 주변 생육형: 물하늘지기
(2) 저수위선 생육형: 하늘지기, 암하늘지기, 좀민하늘 지기

4) 산지습지형

(1) 임도변, 임연부 물이 고인 지역 생육형: 검정하늘지기

(2) 산지습지 생육형: 어른지기, 진도하늘지기, 꼴하 늘지기

5) 경작지 농수로 주변 생육형: 밭하늘지기, 애기하늘 지기, 바람하늘지기

6) 임도, 사면, 나대지 등 생육형: 하늘지기, 털하늘지기

\section{3. 생활형}

생활형은 일년생형, 다년생형으로 구분되었다.

1) 일년생형: 민하늘지기, 암하늘지기, 좀민하늘지기, 바람하늘지기, 애기하늘지기, 털하늘지기, 하늘지기, 바 위하늘지기, 밭하늘지기, 푸른하늘지기로 10 분류군으로 나타났다.

2) 다년생형: 쇠하늘지기, 갯하늘지기, 큰하늘지기, 남 하늘지기, 꼴하늘지기, 검정하늘지기, 물하늘지기, 진도 하늘지기, 들하늘지기, 어른지기, 털잎하늘지기로 11 분류 군으로 나타났다.

\section{형태학적 연구}

1. 지하경

지하경은 길게 뻗는 장경형(long), 비스듬히 기거나 길 게 뻗는 지하경이 있는 혼합형(mixed), 짧은 지하경을 가 지는 단경형(short), 지하경이 없는 무경형(absent)으로 구 분되었다.

1) 장경형: 진도하늘지기, 들하늘지기에서 나타났다 (Fig. 2A).

2) 혼합형: 털잎하늘지기, 남하늘지기, 갯하늘지기에서 나타났다(Fig. 2C).

3) 단경형: 쇠하늘지기, 검정하늘지기, 꼴하늘지기, 물 하늘지기, 어른지기, 큰하늘지기에서 나타났다(Fig. 2B).

4) 무경형: 민하늘지기, 바람하늘지기, 바위하늘지기, 밭 하늘지기, 암하늘지기, 애기하늘지기, 좀민하늘지기, 털하 늘지기, 푸른하늘지기, 하늘지기에서 나타났다(Fig. 2D).

\section{2. 초상엽}

줄기 기부에 엽신이 없는 초상엽만 있는 형, 아래쪽 1-2 개만 엽신 없는 초상엽이 나타나는 형, 엽신이 없는 초상 엽과 엽신이 있는 잎이 섞여 나는 형, 초상엽이 없이 엽신 이 있는 잎만 나는 형로 구분되었다.

1) 초상엽 형: 검정하늘지기, 물하늘지기는 화경줄기 아 래에 초상엽만 있으며, 엽신이 있는 잎은 영양경 (vegetative shoot)에서 나오는 것으로 나타났다(Fig. 2I).

2) 아래쪽 1-2개만 초상엽인 형: 민하늘지기, 암하늘지 기, 갯하늘지기, 들하늘지기, 바람하늘지기에서 나타났다 (Fig. 2K). 


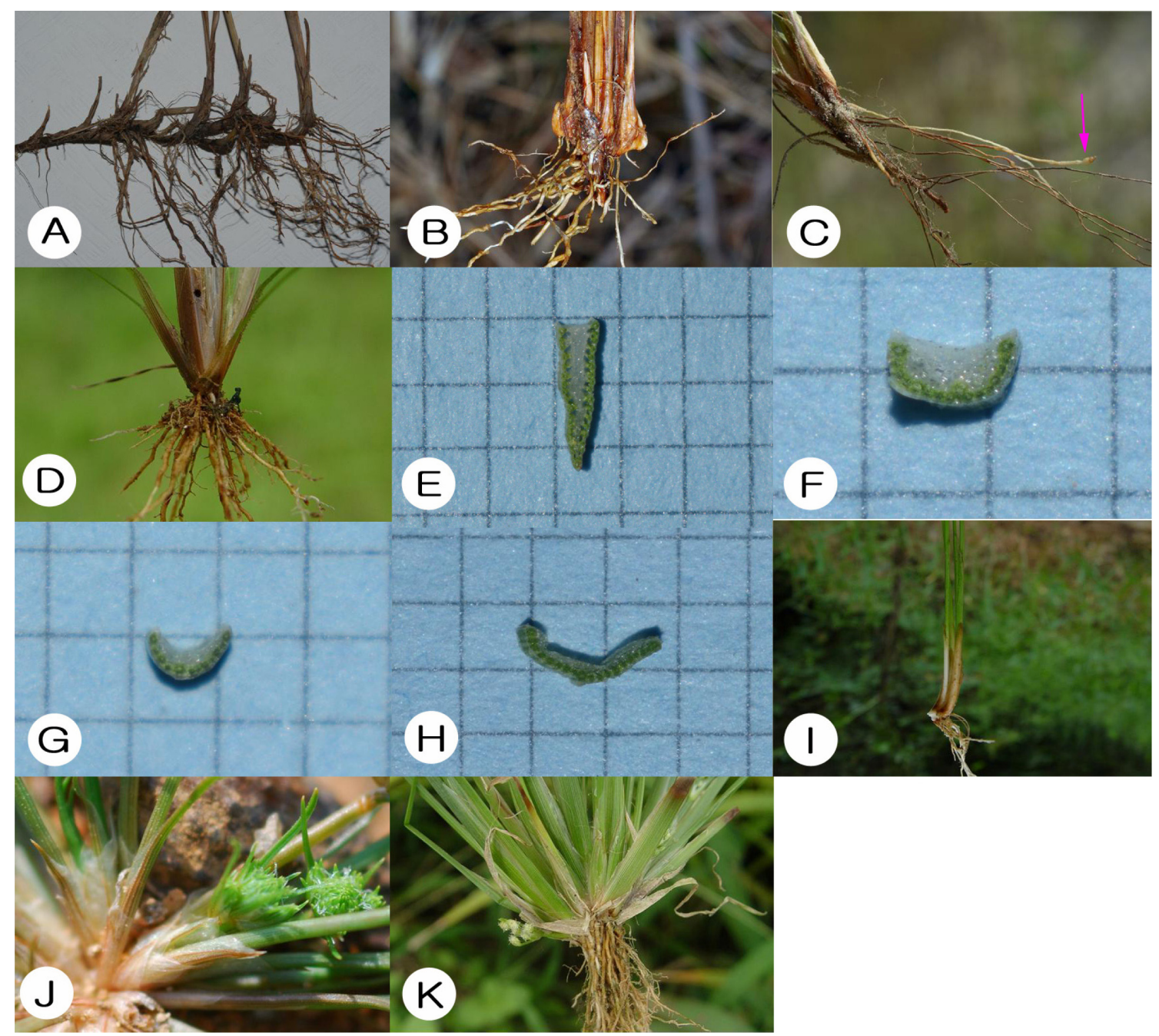

Fig. 2. Key to characteristics of Korean Fimbristylis species. A. Long rhizome. B. Shot rhizome. C. Mixed rhizome. D. Absence of rhizome. E. Compress leaf. F. Folded leaf. G. Convex leaf. H. Flat leaf. I. All Bladeless sheath. J. Mixed sheath. K. Basal bladeless sheath.

3) 혼합형: 푸른하늘지기에서 나타났다(Fig. 2J).

4) 엽신형: 좀민하늘지기, 털잎하늘지기, 꼴하늘지기, 바위하늘지기, 큰하늘지기, 털하늘지기, 하늘지기, 남하 늘지기, 진도하늘지기, 어른지기, 애기하늘지기에서 나타 났다.

\section{3. 잎의 횡단면}

잎 횡단면은 강하게 눌리는 압착형(compress), 말려서 거의 원통형이 되는 원통형(folded), 안쪽으로 반쯤 말리는 반곡형(convex), 잎이 접히지 않고 편평한 편평형(flat)으 로 구분되었다.

1) 압착형: 바람하늘지기에서 나타났다(Fig. 2E).

2) 원통형: 갯하늘지기에서 나타났다(Fig. $2 \mathrm{~F}$ ).

3) 반곡형: 쇠하늘지기, 꼴하늘지기에서 나타났다(Fig. $2 \mathrm{G})$.
4) 편평형: 검정하늘지기, 남하늘지기, 들하늘지기, 물 하늘지기, 민하늘지기, 바위하늘지기, 밭하늘지기, 암하 늘지기, 애기하늘지기, 어른지기, 좀민하늘지기, 좀민하 늘지기, 큰하늘지기, 털잎하늘지기, 털하늘지기, 푸른하 늘지기, 하늘지기에서 나타났다(Fig. $2 \mathrm{H}$ ).

\section{4. 엽설}

엽설은 가는 털로 된 엽설이 있는 형, 엽설이 없는 형으 로 구분되었다.

1) 엽설이 있는 형: 밭하늘지기, 민하늘지기, 암하늘지 기, 꼴하늘지기, 갯하늘지기, 털하늘지기, 하늘지기, 남하 늘지기, 진도하늘지기, 애기하늘지기, 어른지기에서 나타 났다(Fig. 3F).

2) 엽설이 없는 형: 푸른하늘지기, 털잎하늘지기, 좀민 하늘지기, 바위하늘지기, 큰하늘지기, 바람하늘지기, 들 


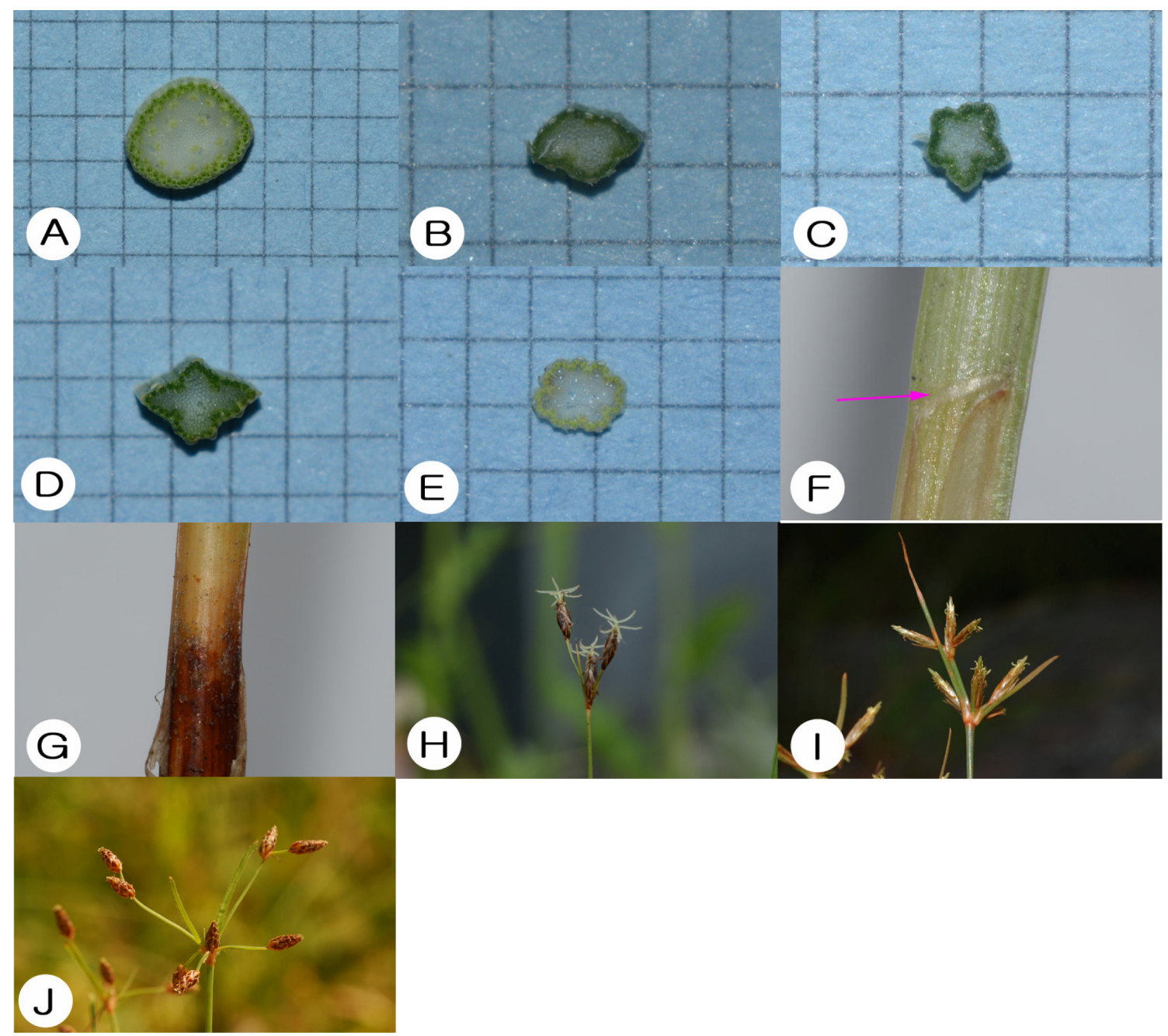

Fig. 3. Key to characteristics of Korean Fimbristylis species. A. Round culm. B. 2-4 deeply striated culm. C. 5-6 angled culm. D. Compres 4angled culm. E. Shallow striated culm. F. Ciliate ligule. G. Absent ligule. H. Simple inflorescence. I. Mixed inflorescence. J. Branch inflorescence.

하늘지기, 쇠하늘지기, 검정하늘지기, 물하늘지기에서 나 타났다(Fig. 3G).

\section{5. 줄기 횡단면(culm cross-section shape)}

줄기 횡단면이 홈이 없는 원형-타원형, 2-3개의 홈이 있 는 원형-타원형, 5-6개의 깊은 홈을 가진 원형-타원형, 눌 린 십자형, 얕은 홈이 진 형으로 구분되었다.

1) 홈이 없는 원형-타원형: 밭하늘지기, 털잎하늘지기, 꼴하늘지기, 바위하늘지기, 갯하늘지기, 큰하늘지기, 남 하늘지기, 진도하늘지기에서 나타났다(Fig. 3A).

2) 2-4개의 깊은 홈이 진 원형-타원형: 좀민하늘지기, 민 하늘지기, 암하늘지기, 어른지기, 애기하늘지기에서 나타 났다(Fig. 3B).

3) 5-6개의 깊은 홈이 진 원형-타원형: 푸른하늘지기, 들
하늘지기, 검정하늘지기, 물하늘지기에서 나타났다(Fig. 3C).

4) 얕은 홈이 진 원형-타원형: 쇠하늘지기, 털하늘지기, 하늘지기에서 나타났다(Fig. 3E).

5) 눌린 십자형: 바람하늘지기에서 나타났다(Fig. 3D).

\section{6. 화서의 형태(inflorescence form)}

화서는 줄기 끝에 1 개(매우 드물게 2개)만 정생하는 단 순형(simple), 가지 끝에 2-4개의 소수가 뭉치는 혼합형 (mixed), 가지가 여러번 분지하는 분지형(branch)으로 구 분되었다.

1) 단순형: 줄기 끝에 하나의 소수만 달리는 화서는 꼴 하늘지기, 쇠하늘지기에서 나타나고, 2 차 가지를 치지 않 는 단순한 화서는 들하늘지기에서 나타나며, 대부분 1 차 
가지만 있으나 매우 드물게 2 차 가지를 내는 화서는 갯하 늘지기에서 나타났다(Fig. 3H).

2) 혼합형: 털잎하늘지기, 바위하늘지기, 남하늘지기에 서 나타났다(Fig. 3I).

3) 분지형: 푸른하늘지기, 밭하늘지기, 좀민하늘지기, 민하늘지기, 암하늘지기, 큰하늘지기, 털하늘지기, 하늘 지기, 바람하늘지기, 진도하늘지기, 검정하늘지기, 물하 늘지기, 어른지기, 애기하늘지기에서 나타났다(Fig. 3J).

\section{7. 소수 모양(spikelet shape)}

소수 모양은 장타원형(oblong), 장타원상 난형, 타원형난형(oval to ovoid), 난형, 거의 구형에서 난형, 좁고 긴 난 형(narrowly ovoid)으로 구분되었다. 소수가 다소 납작하 게 눌리는 것은 쇠하늘지기에서만 관찰되었다.

1) 장타원형: 민하늘지기, 좀민하늘지기, 암하늘지기, 들하늘지기, 어른지기, 애기하늘지기, 진도하늘지기에서 나타났다(Fig. 4D-F, P, Q, T, U).

2) 난형-장타원상 난형(ovoid to oblong-ovoid): 쇠하늘지 기, 밭하늘지기, 푸른하늘지기, 털잎하늘지기, 꼴하늘지 기, 갯하늘지기, 큰하늘지기, 털하늘지기, 하늘지기, 남하 늘지기, 검정하늘지기 에서 나타났다(Fig. 4A-C, G, I-N, $\mathrm{R})$.

3) 타원형-난형: 물하늘지기에서 나타났다(Fig. 4S).

4) 구형-난형(globose to ovoid): 바람하늘지기에서 나타 났다(Fig. 4O).

5) 좁고 긴 난형: 바위하늘지기에서 나타났다(Fig. $4 \mathrm{H})$.

\section{8. 인편 끝(scale apex)}

인편의 끝이 까락형(A), 예두-예첨두형(B), 둔두-원두 형 $(\mathrm{C})$, 미철두형 $(\mathrm{D})$ 으로 구분되었다.

1) 까락처럼 발달하는 형: 푸른하늘지기, 밭하늘지기, 민하늘지기에서 나타났다(Fig. 5B, C, E).

2) 예두-예첨두형: 암하늘지기, 들하늘지기, 진도하늘 지기, 애기하늘지기, 어른지기에서 나타났다(Fig. 5F, P, Q, $\mathrm{T}, \mathrm{U})$.

3) 둔두-원두형: 바람하늘지기, 검정하늘지기, 물하늘 지기에서 나타났다(Fig. 5O, R, S).

4) 미철두(mucronate)형: 쇠하늘지기, 좀민하늘지기, 털 잎하늘지기, 갯하늘지기, 꼴하늘지기, 바위하늘지기, 큰 하늘지기, 털하늘지기, 하늘지기, 남하늘지기에서 나타났 다(Fig. 5A, D, G-N).

\section{9. 약의 길이}

약의 길이가 $0.5 \mathrm{~mm}$ 미만인 형과 $0.5 \mathrm{~mm}$ 이상인 형으로 구분되었다

1) $0.5 \mathrm{~mm}$ 미만인 형: 푸른하늘지기, 밭하늘지기, 민하 늘지기, 암하늘지기, 좀민하늘지기, 털하늘지기, 바람하 늘지기, 검정하늘지기, 물하늘지기, 애기하늘지기에서 나
타났다.

2) $0.5 \mathrm{~mm}$ 이상인 형: 털잎하늘지기, 갯하늘지기, 꼴하 늘지기, 바위하늘지기, 큰하늘지기, 하늘지기, 남하늘지 기, 들하늘지기, 쇠하늘지기, 진도하늘지기, 어른지기에 서 나타났다.

외부형태가 유사한 털하늘지기는 약의 길이가 0.4 $0.6 \mathrm{~mm}$ 였으나 하늘지기는 $0.6-1.5 \mathrm{~mm}$ 로 구별되었고, 들 하늘지기는 약의 길이가 $1.9-2.3 \mathrm{~mm}$ 였으나 진도하늘지기 는 1.1-1.5 mm로 구별되며, 어른지기는 $1.2-1.6 \mathrm{~mm}$ 였으나 애기하늘지기는 $0.3-0.5 \mathrm{~mm}$ 로 구별되어 식별에 유용한 형질로 확인되었다.

\section{0. 화주}

화주는 납작하게 눌리며 가장자리에 털이 있는 형, 암술 머리 쪽과 기부 쪽에 긴 털이 있는 형, 기부 쪽에만 짧은 털 이 있는 형, 납작하게 눌리지만 털이 없는 형, 삼릉형이고 털이 없는 형으로 구분되었다.

1) 납작하게 눌리며 가장자리에 털이 있는 형: 꼴하늘지 기, 쇠하늘지기, 바위하늘지기, 갯하늘지기, 큰하늘지기, 털하늘지기, 하늘지기, 남하늘지기에서 나타났다(Fig. 6A, G-M).

2) 암술머리 쪽과 기부쪽에 긴 털이 있는 형: 민하늘지 기와 암하늘지기에서 나타났다(Fig. $6 \mathrm{E}, \mathrm{F})$.

3) 기부쪽에만 짧은 돌기 털이 있는 형: 털잎하늘지기에 서 나타났다(Fig. $6 \mathrm{~N}$ ).

4) 납작하게 눌리지만 털이 없는 형: 푸른하늘지기, 밭 하늘지기, 좀민하늘지기에서 나타났다(Fig. 6B-D).

5) 삼릉형이고 털이 없는 형: 바람하늘지기, 들하늘지기, 진도하늘지기, 검정하늘지기, 물하늘지기, 어른지기, 애 기하늘지기에서 나타났다(Fig. 6O-U).

외부형태가 유사한 들하늘지기는 약의 길이가 2.5$3.1 \mathrm{~mm}$ 였으나 진도하늘지기는 $1.6-1.5 \mathrm{~mm}$ 로 구별되며, 물하늘지기는 $0.8-1.2 \mathrm{~mm}$ 였으나 검정하늘지기는 0.6$0.8 \mathrm{~mm}$ 로 구별되었고, 어른지기는 $1.4-1.8 \mathrm{~mm}$ 였으나 애 기하늘지기는 0.7-0.9 mm로 구별되어 식별에 유용한 형 질로 확인되었다.

\section{1. 수과 모양(achene shape)}

수과 모양은 원통상 장타원형, 삼릉형, 양철형, 삼릉형 또는 삼릉형과 양철형의 중간형으로 구분되었다.

1) 원통상 장타원형: 푸른하늘지기와 밭하늘지기에서 나타났다(Fig. 7B, C).

2) 삼릉형: 털잎하늘지기, 쇠하늘지기, 바람하늘지기, 들하늘지기, 진도하늘지기, 어른지기, 애기하늘지기에서 나타났다(Fig. 7A, N-Q, T, U).

3) 양철형: 민하늘지기, 암하늘지기, 좀민하늘지기, 꼴 하늘지기, 바위하늘지기, 갯하늘지기, 큰하늘지기, 털하 늘지기, 하늘지기, 남하늘지기에서 나타났다(Fig. 7D-M). 


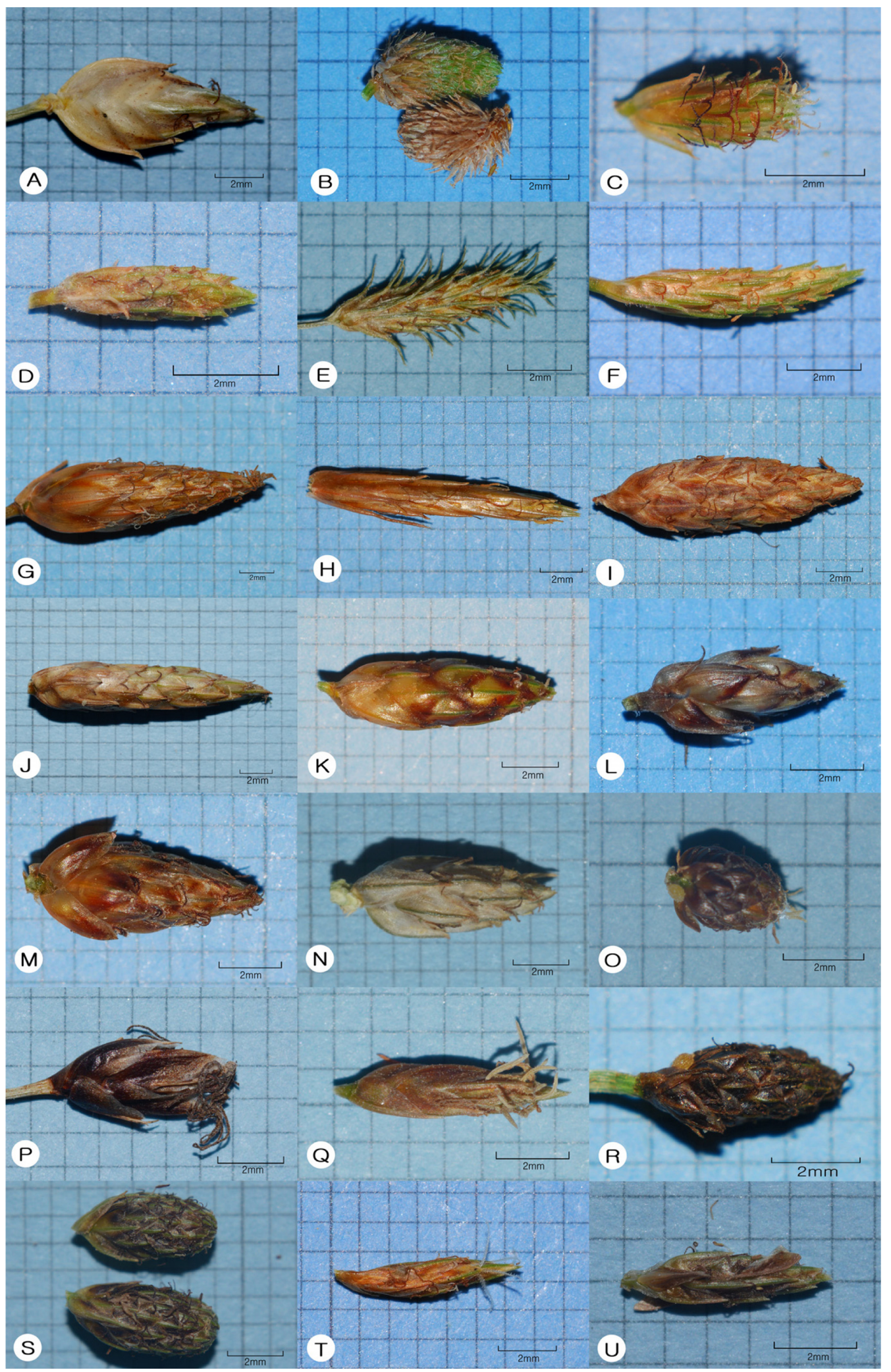

Fig. 4. Spikelet of Korean Fimbristylis. A. F. ovate. B. F. dipsacea var. verrucifera. C. F. stauntonii. D. F. aestivalis. E. F. squarrosa var. squarrosa. F. F. squarrosa var. esquarrosa. G. F. subbispicata. H. F. hookeriana. I. F. sieboldii. J. F. longispica. K. F. tomentosa. L. F. dichotoma var. dichotoma. M. F. dichotoma var. floribunda. N. F. sericea. O. F. littoralis. P. F. pierotii. Q. F. jindoensis. R. F. diphylloides. S. F. drizae. T. F. exaltata. U. F. autumnalis. 


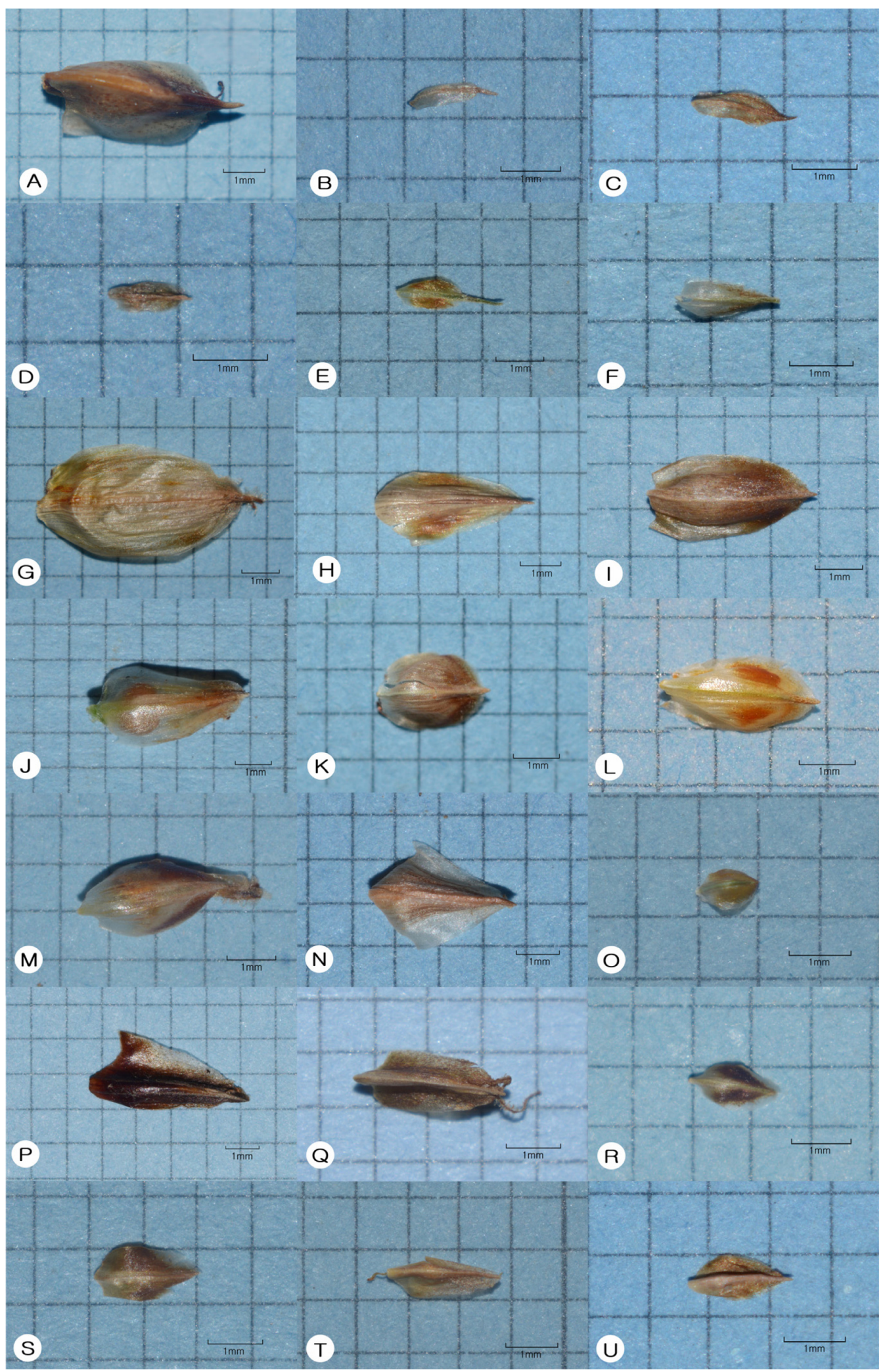

Fig. 5. Scale of Korean Fimbristylis. A. F. ovate. B. F. dipsacea var. verrucifera. C. F. stauntonii. D. F. aestivalis. E. F. squarrosa var. squarrosa. F. F. squarrosa var. esquarrosa. G. F. subbispicata. H. F. hookeriana. I. F. sieboldii. J. F. longispica. K. F. tomentosa. L. F. dichotoma var. dichotoma. M. F. dichotoma var. floribunda. N. F. sericea. O. F. littoralis. P. F. pierotii. Q. F. jindoensis. R. F. diphylloides. S. F. drizae. T. F. exaltata. U. F. autumnalis. 


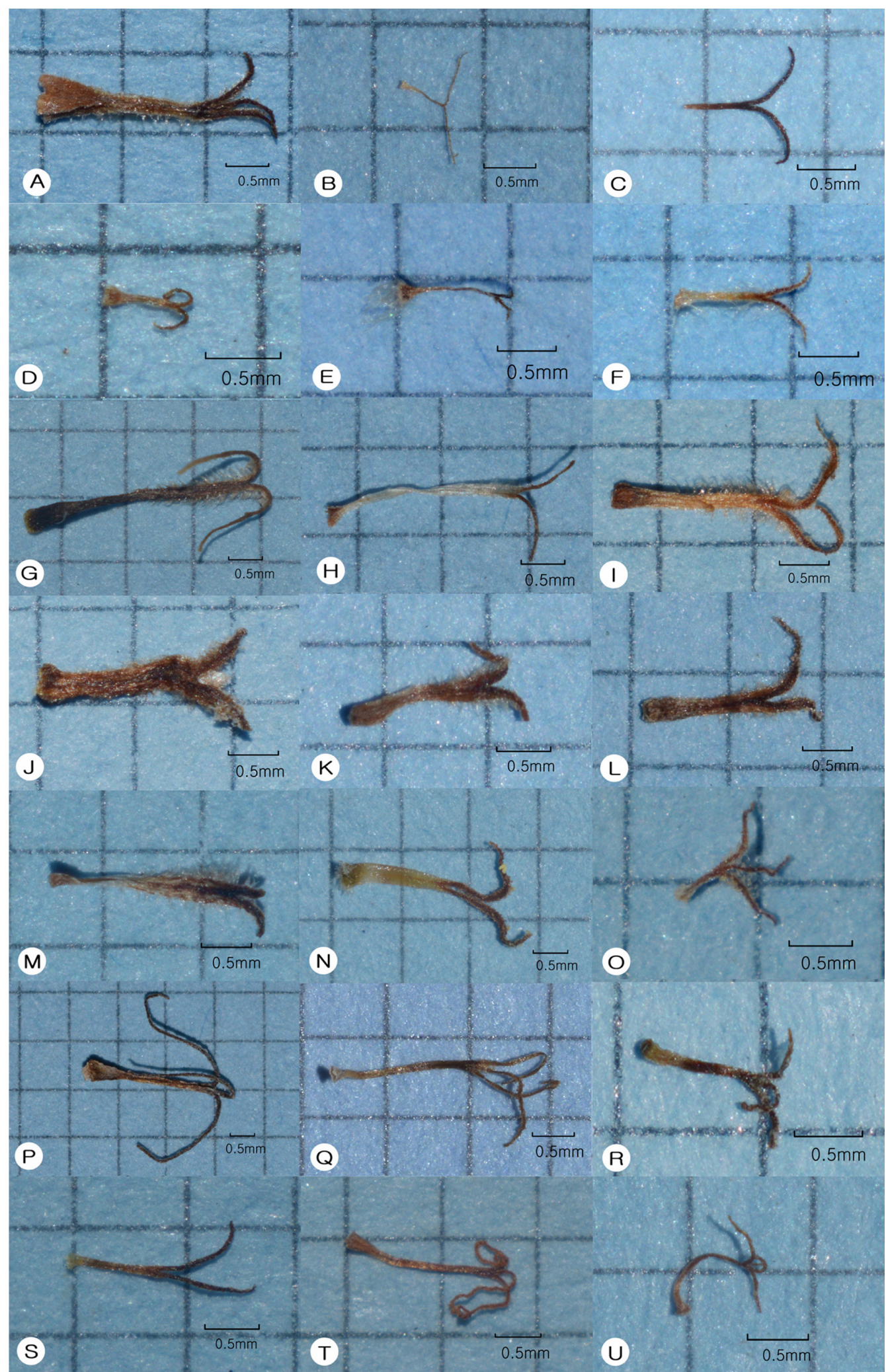

Fig. 6. Style of Korean Fimbristylis. A. F. ovate. B. F. dipsacea var. verrucifera. C. F. stauntonii. D. F. aestivalis. E. F. squarrosa var. squarrosa. F. F. squarrosa var. esquarrosa. G. F. subbispicata. H. F. hookeriana. I. F. sieboldii. J. F. longispica. K. F. tomentosa. L. F. dichotoma var. dichotoma. M. F. dichotoma var. floribunda. N. F. sericea. O. F. littoralis. P. F. pierotii. Q. F. jindoensis. R. F. diphylloides. S. F. drizae. T. F. exaltata. U. F. autumnalis. 


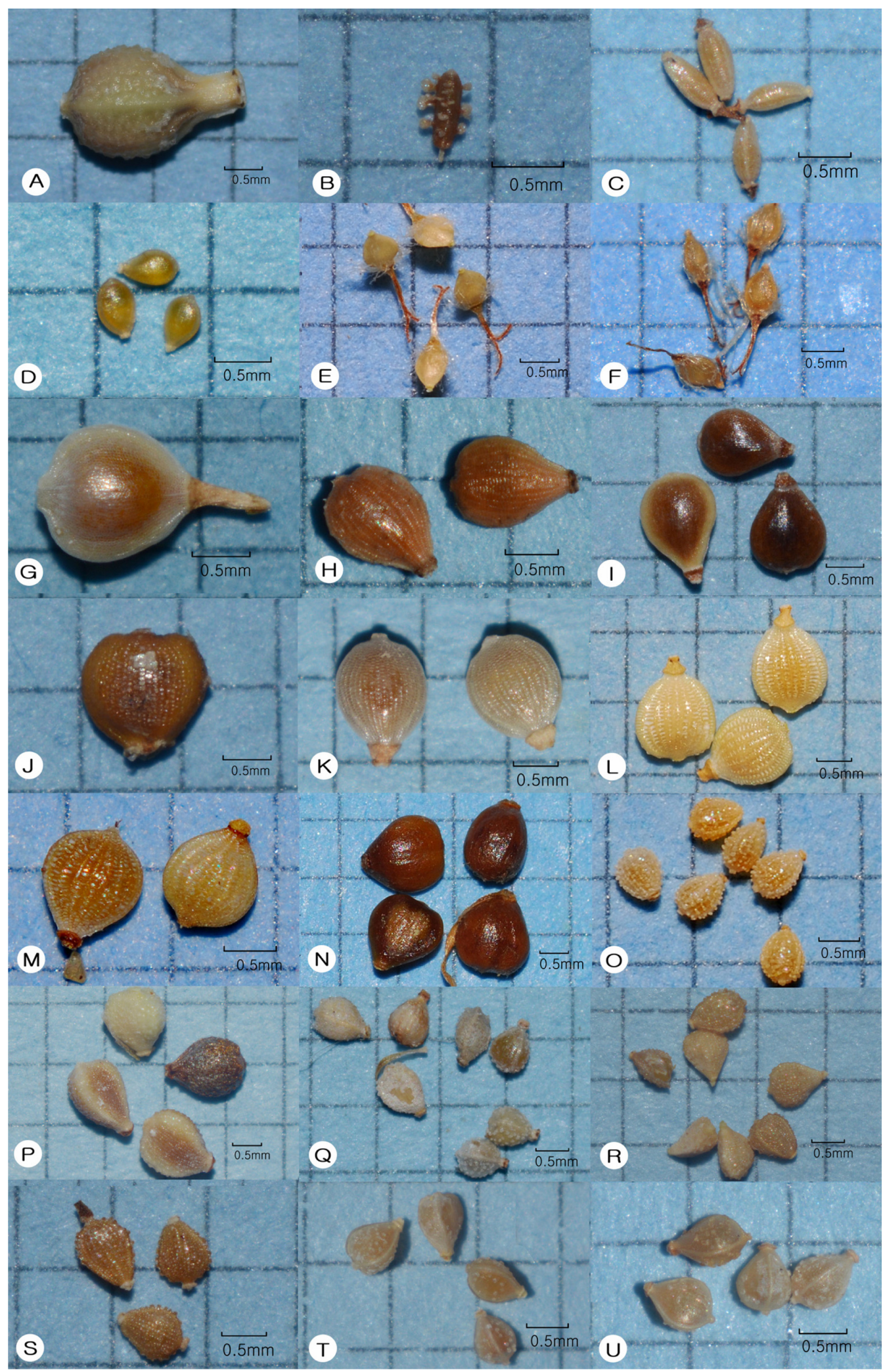

Fig. 7. Achene of Korean Fimbristylis. A. F. ovate. B. F. dipsacea var. verrucifera. C. F. stauntonii. D. F. aestivalis. E. F. squarrosa var. squarrosa. F. F. squarrosa var. esquarrosa. G. F. subbispicata. H. F. hookeriana. I. F. sieboldii. J. F. longispica. K. F. tomentosa. L. F. dichotoma var. dichotoma. M. F. dichotoma var. floribunda. N. F. sericea. O. F. littoralis. P. F. pierotii. Q. F. jindoensis. R. F. diphylloides. S. F. drizae. T. F. exaltata. U. F. autumnalis. 
4) 삼릉형 또는 삼릉형과 양철형의 중간형: 검정하늘지 기, 물하늘지기에서 나타났다(Fig. 7R, S).

12. 수과 표면(achene surface)

수과 표면에 돌기가 있는 형, 격자무늬가 있는 형, 돌기 와 무늬가 없는 형으로 구분되었다.

1) 돌기가 있는 형: 푸른하늘지기, 바람하늘지기, 들하 늘지기, 진도하늘지기, 검정하늘지기, 물하늘지기, 어른 지기, 애기하늘지기, 쇠하늘지기에서 나타났다(Fig. 7A, $\mathrm{B}, \mathrm{O}-\mathrm{U})$.

2) 격자무늬(reticulation)가 있는 형: 밭하늘지기, 꼴하늘 지기, 바위하늘지기, 큰하늘지기, 털하늘지기, 하늘지기, 남하늘지기에서 나타났다(Fig. 7C, G, H, J-M).

3) 돌기와 무늬가 없는 형: 털잎하늘지기, 좀민하늘지기, 민하늘지기, 암하늘지기, 갯하늘지기에서 나타났다(Fig. 7D-F, I, N).

\section{분류군의 기재}

하늘지기속: Fimbristylis Vahl, Enum. P1. 2: 285, 1805.TYPE: Fimbristylis acuminate.

1 년초 또는 다년초로 모여 나거나 긴 지하경이 있기도 하며, 줄기는 사각형-원형이며, 포엽은 있고, 화서는 단생 하는 단순화서이거나 복생하는 복잡한 화서이고, 소수 인 편은 돌려나며 끝이 뾰족하거나 까락이 달린다. 화주는 납작하게 눌리거나 눌리지 않으며, 가장자리에 털이 있거 나 없다. 수술의 개수는 1-3개, 암술머리는 2-3개로 갈라 진다. 수과의 단면은 삼릉형, 원통형이거나 양면이 볼록 한 양철형이다.

하늘지기속은 세계적으로 300 여 분류군 이상이 있으며 (Govaerts and Simpson, 2007; Govaerts, 2010), 한국에 분포하 는 하늘지기속 식물은 약 20 분류군인 것으로 알려져 있다 (Lee, 1980; Lee, 1996; Im, 2000; Oh, 2007; Cho et al., 2016).

\section{한국산 하늘지기속(Fimbristylis)의 종 검색표}

1. 소수는 약간 눌리며, 인편은 마주 보며 2열로 달린다 (sect. Abildgaardia 쇠하늘지기절)

쇠하늘지기 F. ovata

1. 소수는 눌리지 않으며, 인편은 돌려 달린다

2. 수과는 원주상이고 단면이 둥글다(sect. Mischospora 밭하늘지기절)

3. 수과 표면에 격자무늬가 없고, 가장자리에 돌 기가 있다

........ 푸른하늘지기 F. dipsacea var. verrucifera 3. 수과 표면에 격자무늬가 있고, 가장자리에 돌 기가 없다 ……………... 밭하늘지기 F. stauntonii

2. 수과는 도란형이거나 삼릉형으로 단면이 양철형 이거나 삼릉형이다
4. 암술머리는 2 개로 갈라지고, 화주에 털이 있거나 없 으며, 수과 단면이 양철형이거나 삼릉형이다(sect.

Fimbristylis 하늘지기절)

5. 화주에 털이 없다 ............... 좀민하늘지기 F. aestivalis 5. 화주에 털이 있다

6. 화주 기부와 상부에 털이 있다

7. 인편 중륵이 까락처럼 길어 밖으로 휜다

................. 민하늘지기 F. squarrosa var. squarrosa

7. 인편 중륵이 짧게 돌출한다

.. 암하늘지기 F. squarrosa var. esquarrosa

6. 화주 기부에 털이 없고 상부에만 털이 있다

8. 화서에 소수는 1 개가 단생한다

꼴하늘지기 F. subbispicata

8. 화서에 소수는 2 개 이상이 복생한다

9. 소수는 좁고 긴 장타원형이다

바위하늘지기 F. hookeriana.

9. 소수는 난형-장난형이다

10. 잎은 말려서 반 원통형이고, 인편에 털이 있으며, 수과 표면에 무늬가 없 다

갯하늘지기 F. sieboldii

10. 잎은 말리지 않아서 편평하고, 인편에 털이 없으며, 수과 표면에 격자무늬가 있다

11. 수과 표면에 12-20줄의 희미한 격 자무늬가 있다

12. 식물체에 털이 없고, 근경이 짧 게 뻗어 느슨하게 나며, 소수는 난형-장타원형이다

......... 큰하늘지기 F. longispica

12. 식물체 한 군데 이상에 털이 있 고, 근경이 없어 빽빽하게 모여 나며, 소수는 난형이다

......... 털하늘지기 F. tomentosa

11. 수과 표면에 7-11줄의 뚜렷한 격 자무늬가 있다

13. 근경이 없으며 있어도 짧고, 화 서는 가지 끝에 1 개씩 달린다 $\cdots$ ..... 하늘지기 F. dichotoma var. dichotoma

13. 짧지만 뻗는 근경이 있고, 화서 는 긑에 2-5개씩 모여 달린다 $\cdots$ ... 남하늘지기 F. dichotoma var. floribunda

4. 암술머리는 3 개(드물게 2 개)로 갈라지고, 화주에 털 이 없으나 드물게 있으며, 수과 단면이 삼릉형이다 (sect. Trichelostylis 애기하늘지기절)

14. 수과 표면에 돌기가 없고, 화주 기부에 약간의 돌 
기 털이 있다

털잎하늘지기 F. sericea

14. 수과 표면에 돌기가 있고, 화주에 털이 없다

15. 줄기 기부가 납작하게 눌리며, 횡단면은 십자 형이다 바람하늘지기 F. littoralis

15. 줄기 기부가 납작하지 않으며, 횡단면은 십자 형이 아니다

16. 옆으로 뻗는 지하경이 있고, 줄기는 단생 한다

17. 화서에 소수는 10 개 미만이고, 인편은 $4 \mathrm{~mm}$ 이상이다 ... 들하늘지기 F. pierotii

17. 화서에 소수는 20 개 이상이고, 인편은 $4 \mathrm{~mm}$ 미만이다

진도하늘지기 F. jindoensis

16. 옆으로 뻗는 지하경이 없고, 줄기는 총생 한다

18. 화서가 달리는 줄기에 엽신이 없는 초 상엽만 있다

19. 줄기가 잎보다 길고, 소수는 난형, 인편은 흑갈색, 암술머리가 갈라 지는 곳까지 화주 길이가 $0.5-$ $0.8 \mathrm{~mm}$ 이다

........ 검정하늘지기 F. diphylloides

19. 줄기가 잎보다 짧고, 소수는 타원 형, 인편은 황갈색, 암술머리가 갈 라지는 곳까지 화주 길이가 $0.8-$ $1.2 \mathrm{~mm}$ 이다.. 물하늘지기 F. drizae

18. 화서가 달리는 줄기에 엽신이 있는 잎 이 있다

20. 다년생, 인편은 길이 $2.2-3.2 \mathrm{~mm}$, 약은 3 개, 길이 $1 \mathrm{~mm}$ 이상이다 ..... 어른지기 F. exaltata

20. 일년생, 인편은 길이 1.6-2.1 mm, 약은 1 개, 길이 $1 \mathrm{~mm}$ 이하이다 ...... 애기하늘지기 F. autumnalis

Fimbristylis ovata (Burm.f.) Kern, Blumea 15: 126, 1967 (Fig. 8).-TYPE: Indonesia, Java, Burman s.n. (holotype: B). Carex ovata Burm.f., Fl. Indica, 194, 1768.

Cyperus monostachyos L., Mant. Pl. Altera ii: 180, 1771.

F. monostachya (L.) Hassk., Pl. Jav. Rar.: 61, 1848.

Abildgaardia ovata (Burm. f.) Kral, Sida 4: 72-73, f. 2, 1971.

국명: 쇠하늘지기.

모여 나는 다년초, 화서는 줄기 끝에 정생하는 1개(매우 드물게 2개)의 소수가 달린다. 소수는 다소 눌려 있으며, 난형으로 길이 6.0-9.5 mm, 너비 3.1-4.0 mm로 10개 내외 의 소화가 마주보며 달리고 예두이다. 인편은 난형으로
황녹색이고, 길이 $3.7-5.5 \mathrm{~mm}$, 너비 $3.3-4.4 \mathrm{~mm}$ 로 미철두 이다. 수술은 3개, 약은 황색으로 길이 1.6-2.1 mm이다. 화 주는 아래쪽은 삼릉형이나 위쪽은 납작하고, 길이 1.7$2.2 \mathrm{~mm}$ 로 가장자리에 털이 있다. 암술머리는 3개로 갈라 진다. 수과에는 짧은 자루와 돌기가 있으며, 도란상 둔한 삼릉형으로 길이 2.1-2.4 mm, 너비 1.3-1.5 mm로 회갈색으 로 익는다.

국내분포: 제주(마라도).

국외분포: 일본, 중국, 서남아시아, 아프리카, 중앙아메 리카.

분류학적 검토: Burman (1768)이 인도네시아 자바에서 채집한 표본으로 Carex ovata로 발표하였고, Kern (1967)에 의해 Fimbristylis 속으로 옮겨졌다. 국내 일부 문헌에 F. monostachya로 사용하고 있으나 Linnaeus (1771)에 의하여 Cyperus monostachyos로 발표하였고 Hasskarl (1848)에 의 해 Fimbristylis속으로 옮겨졌다. 기재문 확인결과 $F$. monostachya는 F. ovata와 같은 종으로 판단된다. 국제식물 명명규약 Art. 11.4에 따라 Kern (1967)이 종소명으로 발표 가 가장 빠른 ovata로 조합한 Fimbristylis ovata가 정명이 된다. 줄기 끝에 정생하는 1 개(매우 드물게 2개)의 소수가 달리며, 소수는 다소 눌리고 인편이 2열로 마주보며 달리 는 점이 특징으로 Sect. Abildgaardia (쇠하늘지기절)에 속 하므로 종의 실체에 대한 별다른 이견은 없다. 국립수목 원과 국립생물자원관에 석엽표본이 없어 국내 자생 여부 가 불투명하였지만 이번 연구에서 마라도 초지에 생육하 는 것이 확인되어 도판으로 제시하였다(Fig. 8). 쇠하늘지 기는 아열대 지역에 넓게 분포하므로 마라도가 생육지로 써 북한계인 것으로 추정되어 보호가 필요한 것으로 판단 된다.

Fimbristylis dipsacea (Rottb.) C. B. Clarke var. verrucifera (Maxim.) T. Koyama, J. Fac. Sci. Univ. Tokyo, Sect. 3, Bot. 8: 118, 1961.-TYPE: Russia, Amur, Maack s. n. (holotype: $\mathrm{P}$, photo!).

F. verrucifera (Maxim.) Makino, Bot. Mag. (Tokyo) 9: 259, 1895.

국명: 푸른하늘지기.

모여 나는 1 년초, 소수는 가지 끝에 단생하며 성글게 퍼 지고, 난상 장타원형으로 길이 $2.9-7.8 \mathrm{~mm}$, 너비 1.8$2.5 \mathrm{~mm}$ 로 30 개 이상의 소화가 나선상으로 돌려난다. 인편 은 피침상 장타원형으로 연한 황갈색이고, 길이 1.1$1.5 \mathrm{~mm}$, 너비 $0.2-0.4 \mathrm{~mm}$ 로 끝이 짧은 까락처럼 된다. 수술 은 1 개, 약은 황색으로 길이 $0.2-0.3 \mathrm{~mm}$ 이다. 화주는 편평 하며 길이 0.4-0.6 mm로 털이 없고, 암술머리는 2개로 갈 라진다. 수과는 원통상 장타원형으로 횡단면은 원형이고, 가장자리에 잘 떨어지는 혹 같은 돌기가 있고, 길이 0.4$0.6 \mathrm{~mm}$, 너비 0.1-0.2 mm로 갈색으로 익는다. 


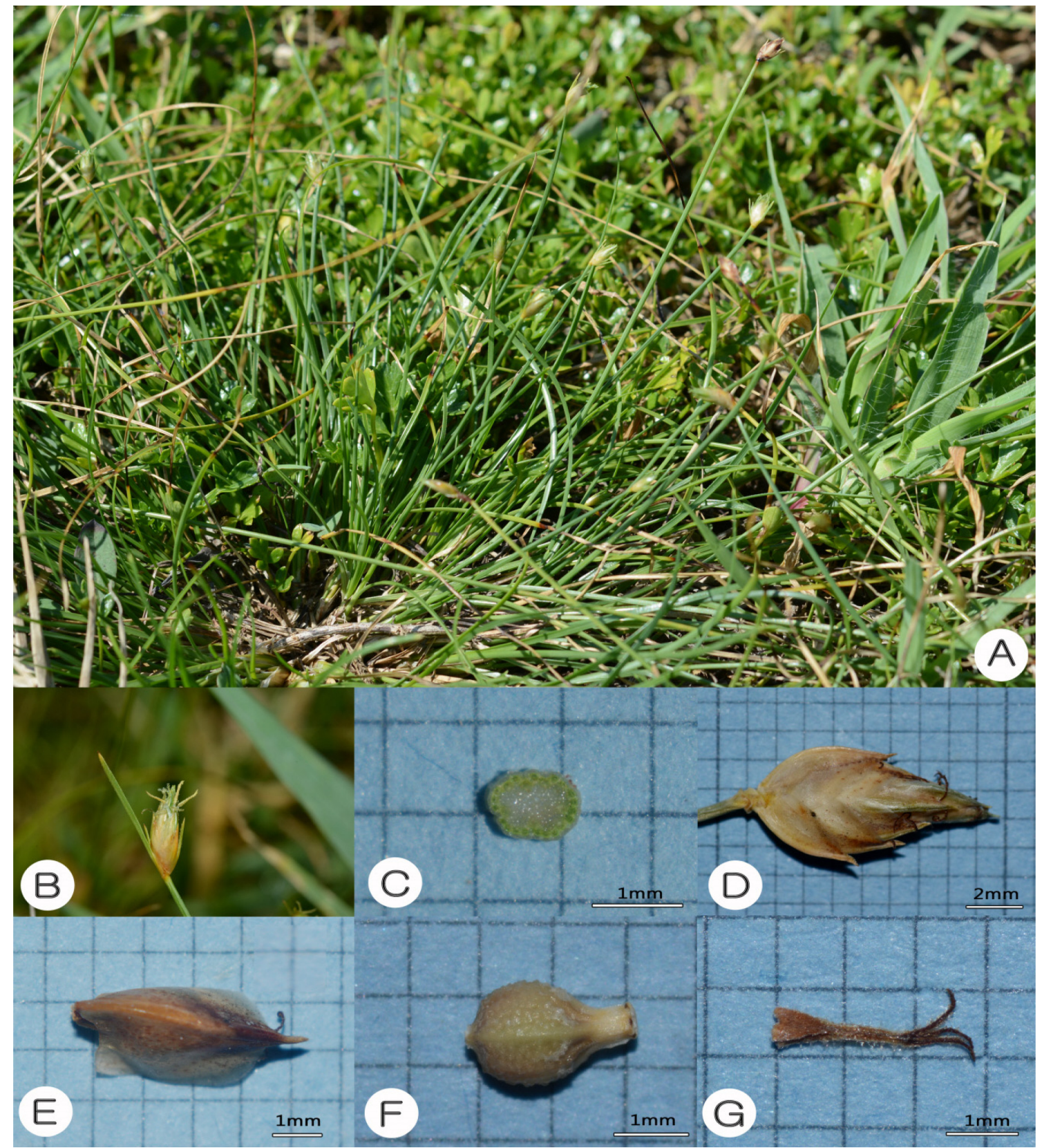

Fig. 8. Photographs of Fimbristylis ovata (Burm.f.) Kern. A. Habit. B. Inflorescence. C. Culm cross-section. D. Spikelet. E. Scale. F. Achene. G. Pistil.

국내분포: 경남, 경북, 전남, 전북.

국외분포: 일본, 중국, 러시아.

분류학적 검토: Maximowicz (1859)가 러시아 아무르지방 에서 Maack가 채집한 표본을 Isolepis속으로 신종기재 하였 으나, Makino (1895)가 하늘지기속으로 이속하였다. Koyama (1961)는 아열대 지방에 분포하는 F. dipsacea와 유 사한 점을 들어 $F$. dipsacea var. verrucifera로 변종으로 처리 하였다. 푸른하늘지기는 한국, 일본, 중국, 극동 러시아 등 동북아시아종으로 인편의 끝이 $0.2-3 \mathrm{~mm}$ 의 짧은 까락상이
나 아열대 분포하는 F. dipsacea는 인편에 길이 $1.0 \mathrm{~mm}$ 이상 긴 까락이 달리는 점을 제외하면 푸른하늘지기와 외부형 태와 수과 등에서 차이점이 뚜렷하지 않아 변종으로 처리 한 견해에 따랐다. 푸른하늘지기는 수과 표면에 잘 떨어지 는 곤봉상 돌기가 있어 속내 분류군과 뚜렷이 구별되었다.

Fimbristylis stauntonii Debeaux and Franch., Actes Soc. Linn. Bordeaux 32: 38 (1878).-TYPE: China, Shan-Tong, Staunton G. 144 (holotype: P, photo!). 
국명: 밭하늘지기.

모여 나는 1년초, 소수는 가지 끝에 단생하며 성글게 퍼 지고, 난형으로 길이 $3.2-5.3 \mathrm{~mm}$, 너비 $1.4-2.0 \mathrm{~mm}$ 로 30 개 이상의 소화가 나선상으로 돌려난다. 인편은 피침상 장타 원형으로 연한 황갈색이고, 길이 $1.6-2.2 \mathrm{~mm}$, 너비 0.2$0.4 \mathrm{~mm}$ 로 끝이 짧은 까락처럼 된다. 수술은 1 개 또는 2개, 약은 황색으로 길이 $0.2-0.3 \mathrm{~mm}$ 이다. 화주는 편평하며 길 이 0.6-0.7 mm로 털이 없으며, 암술머리는 2개 또는 3개로 갈라진다. 수과는 원통상 장타원형으로 횡단면은 원형이 고, 표면에 격자무늬가 있으며, 길이 $0.7 \mathrm{~mm}$, 너비 $0.3 \mathrm{~mm}$ 로 황백색으로 익는다.

국내분포: 강원, 경기, 경남, 경북, 전남, 충북.

국외분포: 일본, 중국.

분류학적 검토: Debeaux and Franch. (1877)가 중국 산동성 에서 Staunton이 채집한 표본을 근거로 신종기재 한 후 종의 실체에 별다른 이견이 없는 분류군이다. 암술머리가 2 개와 3 개로 갈라지는 비율이 약 $2: 1$ 로 2 개로 갈라지는 것의 비율 이 더 높으며 암술머리가 잘 떨어지지 않는 것이 특징적이 다. 주 분포지가 논 경작지와 강변, 저수지 가장자리 등으로 훼손의 위험이 높은 지역으로 과거 제초제 사용으로 인하 여 최근 경작지에서 거의 사라졌고, 경상남도 창녕군 인근 의 경작지에 소규모로 잔존하고 있어 보호대책이 필요하며, 드물게 강변과 저수지 가장자리에 분포하나 수위의 변동성 이 심한 지역의 특성상 관찰이 어려운 것으로 나타났다.

Fimbristylis aestivalis (Retz.) Vahl, Enum. Pl. Obs. 2: 288, 1805.-TYPE: India. König s.n. (isotype: C, photo!).

Scirpus aestivalis Retz., Observ. Bot. 4: 12, 1786.

국명: 좀민하늘지기.

모여 나는 1 년초, 소수는 가지 끝에 단생하며 성글게 퍼 지고, 난형으로 길이 $2.5-5.3 \mathrm{~mm}$, 너비 1.1-1.9 mm로 30 개 이상의 소화가 나선상으로 돌려난다. 인편은 장타원상 난 형으로 갈색이고, 길이 0.9-1.3 mm, 너비 0.4-0.6 mm으로 끝이 미철두이다. 수술은 1 개, 약은 황색으로 길이 $0.2-$ $0.3 \mathrm{~mm}$ 이다. 화주는 편평하며 길이 $0.4-0.6 \mathrm{~mm}$ 로 털이 없 으며, 암술머리는 2 개로 갈라진다. 수과는 도란상 양철형 으로 횡단면은 타원형이고, 표면에 무늬가 없으며, 길이 0.4-0.6 mm, 너비 $0.3 \mathrm{~mm}$ 로 갈색으로 익는다.

국내분포: 전국.

국외분포: 일본, 중국, 러시아, 동남아시아, 호주.

분류학적 검토: Retzii (1786)에 의해 인도산으로 Scirpus aestivalis로 기재되었고, Vahl (1805)에 의해 Fimbristylis속 으로 이속되었다. Kuntze (1891)에 의해 Iria속으로 취급된 적 있으나 종의 실체에 대한 분류학적 이견은 없다. 민하늘 지기, 암하늘지기와 함께 장마 전이나 가을 건기에 물 빠진 저수지에 집단으로 혼생하여 분포하는 경우가 많다. 민하
늘지기, 암하늘지기와 함께 물 빠진 저수지에 집단으로 혼 생하다보니 외부형태가 유사한 암하늘지기와 혼동하는 경우가 많아 Oh and Park (1997)에 의해 국내 자생이 확인 될 때까지 인식하지 못한 분류군이다. 좀민하늘지기는 인 편의 끝이 뽀족한 점에서 암하늘지기와 유사하나 화주 기 부에 긴 털이 없고, 식물체에도 털이 없어 구별되었다.

Fimbristylis squarrosa Vahl var. squarrosa, Enum. pl. 92: 289, 1806.-TYPE: America, Loefling s.n. (holotype: C, photo!).

국명: 민하늘지기.

모여 나는 1년초, 소수는 가지 끝에 단생하며 성글게 퍼 지고, 장타원상 난형으로 길이 $3.5-9.1 \mathrm{~mm}$, 너비 1.2 $1.9 \mathrm{~mm}$ 로 30 개 이상의 소화가 나선상으로 돌려난다. 인편 은 장타원상 난형으로 연한 황갈색이고, 길이 $1.1-1.3 \mathrm{~mm}$, 너비 0.5-0.6 mm로 끝이 까락처럼 되며 밖으로 휘어진다. 수술은 1 개, 약은 황색으로 길이 $0.2-0.3 \mathrm{~mm}$ 이다. 화주는 편평하며 길이 0.6-0.7 mm로 아래쪽과 상부에 긴 털이 있 으며, 암술머리는 2 개로 갈라진다. 수과는 양철형으로 횡 단면은 타원형이고, 표면에 무늬가 없으며, 길이 0.5$0.7 \mathrm{~mm}$, 너비 0.4-0.6 mm로 황백색으로 익는다.

국내분포: 전국.

국외분포: 일본, 중국, 동남아시아, 유럽, 아프리카.

분류학적 검토: Vahl (1806)에 의해 유럽산으로 신종기 재 한 후 종의 실체에 별다른 이견이 없는 분류군으로 분 포지가 북아메리카와 극지방을 제외한 전역으로 분포 범 위가 매우 넓다(Kern, 1974). 한국에서는 가을철과 장마 전 물 빠진 저수지에 비교적 흔하게 집단적으로 발생하는 것 을 볼 수 있다. 화주 기부와 상부에 긴 털이 있어 암하늘지 기와 유사하나 인편에 $1 \mathrm{~mm}$ 내외의 밖으로 굽은 까락이 있으므로 외부형태로 속내 분류군과 구별된다.

var. esquarrosa Makino, Bot. Mag. (Tokyo) 17: 47, 1903.

-TYPE: Japan, Makino s.n. (syntypes: MAK).

F. makinoana Ohwi, J. Jap. Bot. 14: 578, 1938.

F. velata R. Br., Prodr. Fl. Nov. Holl.: 227, 1810.

F. aestivalis (Retz.) Vahl var. squarrosa (Vahl) T. Koyama, J. Fac. Sci. Univ. Tokyo, Sect. 3, Bot. 8: 116, 1961.

국명: 암하늘지기.

모여 나는 1년초, 소수는 가지 끝에 단생하며 성글게 퍼 지고, 장타원상 난형으로 길이 $3.5-9.8 \mathrm{~mm}$, 너비 1.3$1.8 \mathrm{~mm}$ 로 30 개 이상의 소화가 나선상으로 돌려난다. 인편 은 장타원상 난형으로 연한 황갈색이고, 길이 $1.5-1.9 \mathrm{~mm}$, 너비 0.5-0.7 mm로 끝이 뾰족하다. 수술은 1 개, 약은 황색 으로 길이 $0.2-0.3 \mathrm{~mm}$ 이다. 화주는 편평하며 길이 0.6$0.9 \mathrm{~mm}$ 로 아래쪽과 상부에 긴 털이 있으며, 암술머리는 2 
개로 갈라진다. 수과는 양철형으로 횡단면은 타원형이고, 표면에 무늬가 없으며, 길이 $0.5-0.7 \mathrm{~mm}$, 너비 $0.4-0.5 \mathrm{~mm}$ 로 황백색으로 익는다.

국내분포: 전국.

국외분포: 일본, 중국, 동남아시아, 호주.

분류학적 검토: Makino (1903)에 의해 일본산으로 var. esquarrosa로 변종으로 기재되었고, Ohwi (1938)가 F. makinoana를 신종기재하며 var. esquarrosa를 이명으로 처리하였다. 한편 Brown (1810)에 의해 발표된 F. velata 가 암술대가 납작하게 눌리고 기부에 긴 털이 있어 민하 늘지기와 유사하다. Var. esquarrosa를 종으로 취급할 경 우에는 선취권에 따라 F. velata를 사용하는 것이 적법하 나 원변종인 F. squarrosa와 인편의 차이점 이외 특별한 차이가 없어 변종으로 처리한 견해에 따랐고, 변종에서 는 Makino (1903)의 발표가 가장 빠르므로 var. esquarrosa의 학명을 사용하였다. Koyama (1961)는 좀민 하늘지기의 변종 F. aestivalis var. esquarrosa로 취급하기 도 하였으나 화주에 털이 전혀 없는 좀민하늘지기와는 완전히 다르고, 원변종인 민하늘지기와 인편의 차이점 외에는 다른 외부형태에 차이점이 거의 없어 민하늘지 기의 변종으로 취급한 견해에 따랐다.

주 분포지가 가을철과 장마 전의 물 빠진 저수지에 민하 늘지기와 같은 지역에 드물게 섞여 자란다. 화주 기부와 상부에 긴 털이 있어 민하늘지기와 유사하나 인편 끝이 뾰족하여 $1 \mathrm{~mm}$ 내외의 밖으로 굽은 까락이 있는 민하늘 지기와 구별되나 까락이 없고, 자라는 지역이 같은 좀민 하늘지기와 외부형태가 유사하나 좀민하늘지기는 화주 에 털이 없어서 구별되었다.

Fimbristylis subbispicata Nees and Meyen, Nova Act. Acad. Caes. Leop.-Carol. Nat. Cur. 19, Suppl. 1: 75, 1843.-TYPE: China, Meyan and Vachell s.n (holotype: Lindl).

F. tristachya $\mathrm{R}$. Br. var. subbispicata (Nees and Meyen) T. Koyama, J. Fac. Sci. Univ. Tokyo Sect. 3, Bot. 8: 114, 1961. 국명: 꼴하늘지기.

모여 나는 다년초, 소수는 줄기 끝에 1 개만 달리고, 장타 원상 난형으로 길이 $11.0-20.0 \mathrm{~mm}$, 너비 3.8-5.0 mm로 30 개 이상의 소화가 나선상으로 돌려난다. 인편은 장타원상 난형으로 갈색이고, 길이 5.1-6.5 mm, 너비 2.1-2.8 mm로 끝이 미철두이다. 수술은 3 개, 약은 황색으로 길이 $1.3-$ $2.2 \mathrm{~mm}$ 이다. 화주는 편평하며 길이 2.6-3.4 mm로 위쪽에 털이 있으며, 암술머리는 2개로 갈라진다. 수과는 도란상 양철형으로 횡단면은 타원형이고, 아래쪽에 $0.5 \mathrm{~mm}$ 내외 의 자루가 있으며, 표면에 희미한 격자무늬가 있고, 길이 1.7-2.1 mm, 너비 $1.0-1.3 \mathrm{~mm}$ 로 흰색이 섞인 갈색으로 익 는다.

국내분포: 전국.
국외분포: 대만, 베트남, 일본, 중국.

분류학적 검토: Nees and Meyen (1843)에 의해 중국 동부 에서 채집된 것을 근거로 신종기재 하였고 이후 종의 실 체에 별다른 이견이 없다. 그러나 꼴하늘지기는 동북아시 아에 분포하는 분류군으로 동남아시아 및 호주 일대에 분 포하는 F. tristachya와 소수 개수가 많은 것을 제외하면 소 수, 인편, 화주, 수과 등에서 유사한 점이 많다. 따라서 Koyama (1961)는 꼴하늘지기를 $F$. tristachya var. subbispicata로 변종으로 취급하였다. 하지만 꼴하늘지기 는 소수의 개수가 1 개인데 비해 F. tristachya는 최대 11 개 (Kern, 1974)로 외부 형태가 완전히 다르고, 꼴하늘지기는 분포 지역이 동북아시아 온대지역이나 F. tristachya는 서 남아시아의 태평양측 아열대 지역으로 분포지도 달라 금 회 연구에서는 독립된 종으로 취급한 견해에 따랐다. 한 국에 분포하는 하늘지기속 식물 중 꼴하늘지기는 줄기 끝 에 소수 한 개만 달리는 특징으로 속내 분류군과는 외부 형태로 쉽게 식별된다.

Fimbristylis hookeriana Boeck., Linnaea. 37: 22, 1871 TYPE: Indiae Khasia, Hook J. D. 22 (holotype: P, photo!).

국명: 바위하늘지기.

모여 나는 1년초, 소수는 좁은 장타원형으로 길이 6.5$16.9 \mathrm{~mm}$, 너비 1.6-1.8 mm로 10 개 이상의 소화가 나선상으 로 돌려난다. 인편은 난형으로 갈색이고, 길이 3.7$4.5 \mathrm{~mm}$, 너비 1.6-1.8 mm로 끝이 미철두이다. 수술은 2개 또는 3개, 약은 황색으로 길이 0.8-1.1 mm이다. 화주는 편 평하며 길이 1.9-2.6 mm로 위쪽에 털이 있으며, 암술머리 는 2 개로 갈라진다. 수과는 도란상 양철형으로 횡단면은 타원형이고, 표면에 격자무늬가 있고, 길이 $1.0-1.4 \mathrm{~mm}$, 너비 0.8-1.0 mm로 황백색으로 익는다.

국내분포: 경남, 전남, 전북.

국외분포: 동남아시아, 중국.

분류학적 검토: Böeckeler (1871)가 인도산을 근거로 신 종기재 한 후 종의 실체에 대한 분류학적 이견은 없다. 바 위하늘지기는 금회 연구과정에서 확인된 분류군으로 $\operatorname{Kim}$ and Kim (2013)에 의해 한국 미기록종으로 보고되었 다. 바위하늘지기는 남부지방의 건조한 바위 사면에 분포 하는 특징과 가늘고 긴 소수가 밀집하는 화서로 속내 분 류군들과 외부형태로 쉽게 구분되었다. 국외 분포가 중국 남부와 동남아시아인데 한국의 서남부 지방에 분포하는 것이 식물구계학적으로 흥미롭다.

Fimbristylis sieboldii Miq. ex Franch. and Sav., Enum. Pl. Jap. 2: 118, 1877.-TYPE: Japan, Siebold s.n. (holotype: not seen).

F. ferruginea (L.) Vahl. var. sieboldii (Miq. ex Franch. and Sav.) Ohwi., J. Jap. Bot. 14: 576, 1938. 
국명: 갯하늘지기.

모여 나는 다년초, 소수는 좁은 장타원상 난형으로 길이 8.1-20.1 mm, 너비 2.2-3.1 mm로 30개 이상의 소화가 나선 상으로 돌려난다. 인편은 난형으로 갈색으로 위쪽으로 미 세한 털이 있으며, 길이 $3.0-3.5 \mathrm{~mm}$, 너비 1.6-2.1 mm로 끝 이 미철두이다. 수술은 3 개, 약은 황색으로 길이 $0.8-$ $0.9 \mathrm{~mm}$ 이다. 화주는 편평하며 길이 $1.0-1.7 \mathrm{~mm}$ 로 털이 있 으며, 암술머리는 2 개로 갈라진다. 수과는 도란상 양철형 으로 횡단면은 타원형이고, 표면에 육안으로 확인이 어려 운 미세한 무늬가 있고, 길이 $1.0-1.3 \mathrm{~mm}$, 너비 $0.8-1.1 \mathrm{~mm}$ 로 짙은 갈색으로 익는다.

국내분포: 경기, 경남, 전남, 전북, 충남.

국외분포: 일본, 중국.

분류학적 검토: Miquel (1870)이 Siebold가 일본에서 채 집하여 파리표본관에 보관중인 것을 목록으로 남겼으나 적법한 출판이 아니었고, 이후 Franchet and Savatier (1877) 가 합법적으로 출판하여 정당명이 되었다. Ohwi (1938)는 아열대 지방에 분포하는 F. ferrugineae의 변종 var. sieboldii 로 처리하였고, 국내 문헌인 Lee (1980), Lee (1996), Oh (2000) 등도 이 견해대로 변종으로 취급하였다. Zhang et al. (2010), Cho et al. (2016)은 독립된 종으로 취급하였고, Hoshino et al. (2011)는 그 저서에 F. ferrugineae를 쓰고 $F$. sieboldii를 언급하지 않은 것으로 보아 F. sieboldii와 $F$. ferrugineae가 같은 분류군으로 인식한 것으로 판단된다. 하지만 필리핀에서 직접 채집한 F. ferrugineae 관찰 결과 약이 $1 \mathrm{~mm}$ 이상으로 크고, 화주가 $2 \mathrm{~mm}$ 이상으로 길어 금 회 연구에서는 갯하늘지기를 독립된 종으로 처리한 견해 에 따랐다.

Fimbristylis longispica Steud., Syn. Pl. Glumac. 2: 118, 1855- -TYPE: Japan, Goering P.F.W. 10 (holotype: P, photo!). 국명: 큰하늘지기.

느슨히 모여 나는 다년초, 소수는 장타원상 난형으로 길 이 7.1-23.0 mm, 너비 2.8-4.1 mm로 30 개 이상의 소화가 나 선상으로 돌려난다. 인편은 난형으로 연한 갈색이며, 길 이 2.8-4.1 mm, 너비 $2.0-2.5 \mathrm{~mm}$ 로 끝이 미철두이다. 수술 은 3개, 약은 황색으로 길이 $1.0-1.4 \mathrm{~mm}$ 이다. 화주는 편평 하며 길이 1.1-2.2 mm로 털이 있으며, 암술머리는 2개로 갈라진다. 수과는 도란상 양철형으로 횡단면은 타원형이 고, 표면에 격자무늬가 있고, 길이 $1.3-1.5 \mathrm{~mm}$, 너비 1.1$1.4 \mathrm{~mm}$ 로 갈색으로 익는다.

국내분포: 경기, 전남, 전북, 제주, 충남.

국외분포: 일본, 중국.

분류학적 검토: Steudel (1855)이 일본산을 근거로 신종 기재 하였고 이후 종의 실체에 대한 분류학적 이견은 없 다. 큰하늘지기는 바닷가 염습지에 분포하며, 식물체에
털이 없고, 대형으로 줄기 단면이 원형이므로 속내 분류 군과 구별된다. 큰하늘지기는 바닷가 염습지와 하구 기수 역에 분포하는데 과거 채집지역 자료를 바탕으로 해당지 역에서 채집을 시도하였으나 한곳을 제외하고 모두 사라 졌다. 염습지나 하구 기수역 주변이 대부분 제방이 축조 되어있고, 갈대가 우점하고 있어 훼손과 경쟁에서 밀려 큰하늘지기가 사라진 것으로 추정된다. 큰하늘지기는 식 물체 크기와 바닷가 염습지와 기수역에 분포하는 특징으 로 속내 분류군과 뚜렷이 구별된다.

Fimbristylis tomentosa Vahl, Enum. pl. 2: 290, 1805.TYPE: India, Anonymous s.n. (holotype: C. photo!).

F. dichotoma (L.) Vahl var. diphylla (Retz.) T. Koyama for. tomentosa (Vahl) Ohwi, J. Jap. Bot. 14: 577, 1938.

F. dichotoma (L.) Vahl f. tomentosa Ohwi, Fl. Jap. ed. Engl.: 208, in nota, 1965.

국명: 털하늘지기.

모여 나는 1년초, 소수는 난형으로 길이 $3.6-7.5 \mathrm{~mm}$, 너 비 1.9-2.6 mm로 20 개 이상의 소화가 나선상으로 돌려난 다. 인편은 난형으로 갈색이며, 길이 $2.1-2.7 \mathrm{~mm}$, 너비 $1.5-$ $1.8 \mathrm{~mm}$ 로 끝이 미철두이다. 수술은 2 개, 약은 황색으로 길 이 0.4-0.6 mm이다. 화주는 편평하며 길이 $0.8-1.2 \mathrm{~mm}$ 로 털이 있으며, 암술머리는 2 개로 갈라진다. 수과는 도란상 양철형으로 횡단면은 타원형이고, 표면에 11-20줄의 격 자무늬가 있고, 길이 $1.1-1.4 \mathrm{~mm}$, 너비 $0.8-1.2 \mathrm{~mm}$ 로 흰색 으로 익는다.

국내분포: 전남, 제주.

국외분포: 일본, 중국, 동남아시아, 호주, 미국, 서아프리카.

분류학적 검토: Vahl (1805)이 인도산을 근거로 신종기 재하였고, Ohwi (1938)가 F. dichotoma for. tomentosa로 하늘 지기의 품종으로 처리하였으며, Koyama (1964)는 $F$. dichotoma subsp. podocarpa의 이명으로 처리하였고, Zhang et al. (2010)은 하늘지기인 F. dichotoma의 이명으로 처리하 였다. Lee (1980), Oh (2000) 등도 Ohwi (1938)의 견해에 따 라 품종으로 취급하였으나, Kral (1971), Kern (1974), Cho et al. (2016)은 독립된 종으로 취급하였다.

털하늘지기는 외부형태가 하늘지기와 유사해 외부형 태로 식별이 어렵다. 하늘지기와 털하늘지기 모두 털이 거의 없는 것부터 많은 것까지 한 지역에서도 연속적으로 출현하므로 식물체의 털 유무를 근거로 2 분류군을 식별 하는 것은 곤란하다. 특히 전남과 경남 남부의 해안근처 에는 하늘지기와 털하늘지기가 동일 지역에 자라기도 하 나 털하늘지기가 보다 드물게 분포한다. 하늘지기는 7-11 줄의 뚜렷한 장방형의 격자 무늬가 있으나, 털하늘지기는 희미한 13-20줄의 격자무늬가 있으며, 약의 길이가 하늘 지기는 0.6-1.5 mm이나 털하늘지기는 0.4-0.6 mm로 작아 구별되므로 독립된 종으로 취급하는 것이 타당할 것이다. 
Fimbristylis dichotoma (L.) Vahl var. dichotoma, Enum. pl. 2: 287, 1805.-TYPE: India. Anonymous s.n. (syntype: K, photo!).

Scirpus dichotomus L., Sp. PI. 50, 1753.

S. diphyllus Retz. Obs., 5: 15, 1789.

F. diphylla (Retz.) Vahl Enum. Pl., 2: 289, 1805.

F. dichotoma var. tentsuki T. Koyama, J. Jap. Bot. 63: 91, 1988.

국명: 하늘지기.

모여 나는 1년초, 소수는 난형으로 길이 4.2-8.1 mm, 너 비 2.1-3.0 mm로 20개 이상의 소화가 나선상으로 돌려난 다. 인편은 난형으로 갈색이며, 길이 $2.1-2.9 \mathrm{~mm}$, 너비 1.6$2.1 \mathrm{~mm}$ 로 끝이 미철두이다. 수술은 2개, 약은 황색으로 길 이 0.6-1.5 mm이다. 화주는 편평하며 길이 0.8-1.2 mm로 털이 있으며, 암술머리는 2개로 갈라진다. 수과는 도란상 양철형으로 횡단면은 타원형이고, 표면에 7-10줄의 격자 무늬가 있고, 길이 1.2-1.6 mm, 너비 0.9-1.2 mm로 흰색으 로 익는다.

국내분포: 전국.

국외분포: 세계전역.

분류학적 검토: Linnaeus (1753)가 인도산을 Scirpus dichotomus로 발표하였으나, Vahl (1805)이 Fimbristylis속을 설립하며 하늘지기속으로 옮긴 이후 분류학적 논란은 없 다. 하지만 Koyama (1988)는 아열대에 분포하며 짧은 근경 이 있는 다년생과 달리 동북아에 분포하는 것이 1 년생이 라는 점을 들어 한국, 일본, 중국에 분포하는 종을 var. tentsuki로 신변종으로 처리하였다. 그러나 아열대 지방에 도 건조한 지역에 자라는 개체는 건기에 말라 죽는 1 년생 의 특징이 나타나는 것을 직접 관찰하였고, 제주도에서 다 년생인 하늘지기가 확인되어 분포지에 따라 1 년생 내지 다 년생이므로 var. tentsuki는 의미가 없는 것으로 판단된다. 하늘지기는 분포지가 열대, 아열대, 온대에 넓게 분포하므 로 분포지가 다양하여 변이가 심하여 Koyama (1988)는 일 본산으로 다수의 변종과 품종을 기록하였으나 국내분포 하지 않는 분류군은 분류학적 처리를 보류하였다.

한편, Brown (1810)이 호주산을 F. depauperata로 신종으 로 기재하였으나 Clarke (1893)가 F. diphylla var. depauperata 로 변종으로 처리하였고, Ohwi (1938)가 F. dichotoma f. depauperata로 품종으로 처리하였으며, Koyama (1955)는 $F$. spathacea var. depauperata로 처리하였고, Kern (1974)은 $F$. dichotoma subsp. depauperata로 아종 처리하였다. 국내에서 Lee (1980)는 Ohwi (1938)의 견해를 받아들여 가는하늘지 기 f. depauperata를 하늘지기 품종으로 기록하였다. Kern (1974)은 F. depauperata는 호주 북부, 미크로네시아, 뉴기 니 그리고 말레이시아 동남쪽 등 남태평양 일부에만 분포 한다고 하며 아종 F. dichotoma ssp. depauperata로 취급하 였다. F. depauperata는 소수가 1-3개 달리는 점에서 하늘
지기 왜소한 타입과 비슷하나 Zhang et al. (2010)은 호주, 뉴기니 등 남태평양 주변에 분포하고 줄기, 잎, 소화경 등 에 털이 많으며 소수, 인편, 수과 등이 작은 점에서 다르다 고 하였다. 금회 연구에서 F. dichotoma f. depauperata로 판 단되는 분류군은 확인하지 못하였고, 하늘지기는 소수 개 수가 1 개부터 10 개 이상이 동일지역에서 혼생하는 것을 여러 곳에서 확인하였고, 식물체 털도 개체 및 장소에 따 라 거의 없는 것부터 아주 많은 것까지 연속으로 나타났 다. 하늘지기는 외부 형태가 털하늘지기와 유사하여 외모 를 기준으로 하는 구별은 어렵고, 수과의 표면무늬와 약 의 크기가 커서 구별된다. 국내에서 채집된 표본을 확인 한 결과 하늘지기는 전국적으로 분포하나 털하늘지기는 전남, 경남 해안가 이남에만 분포하는 난대성인 것으로 확인되었다.

var. floribunda (Miq.) T. Koyama, J. Jap. Bot. 63: 90, 1988. -TYPE: Japan, Anonymous s.n. (lectotype: L).

F. diphylla (Retz.) var. floribunda Miq., Ann. Mus. Bot. Lugduno-Batavi 2: 145, 1865.

F. dichotoma for. floribunda (Miq.) Ohwi, J. Jap. Bot. 14: 577, 1938.

국명: 남하늘지기.

짧은 지하경이 있는 다년초, 가지끝에 3-5개씩 모여달 리는 소수는 난형으로 길이 $5.2-13.2 \mathrm{~mm}$, 너비 $2.3-3.7 \mathrm{~mm}$ 로 20 개 이상의 소화가 나선상으로 돌려난다. 인편은 난형 으로 갈색이며, 길이 2.5-3.2 mm, 너비 1.6-2.1 mm로 끝이 미철두이다. 수술은 2개, 약은 황색으로 길이 $0.8-1.5 \mathrm{~mm}$ 이다. 화주는 편평하며 길이 $1.2-1.6 \mathrm{~mm}$ 로 털이 있으며, 암 술머리는 2개로 갈라진다. 수과는 도란상 양철형으로 횡 단면은 타원형이고, 표면에 7-10줄의 격자무늬가 있고, 길 이 1.1-1.4 mm, 너비 0.7-1.1 mm로 흰색으로 익는다.

국내분포: 전남, 제주.

국외분포: 일본, 중국.

분류학적 검토: Miquel (1865)이 일본산을 F. diphylla var. floribunda로 변종으로 발표하였으나 Ohwi (1938)가 F. dichotoma for. floribunda로 하늘지기의 품종으로 처리하였 고, Koyama (1988)는 F. dichotoma var. floribunda로 변종으 로 처리하였다.

남하늘지기는 하늘지기에 비하여 지하경이 있는 다년생 으로 줄기가 단생하고, 식물체에 털이 전혀 없으며, 건조한 지역에 자라는 점에서 구별되나 소수, 인편, 수과 등의 생 식기관에서 하늘지기와 뚜렷한 차이가 없어 변종으로 취 급한 Koyama (1988)의 견해를 따라 변종으로 처리하였다.

Fimbristylis sericea R. Br., Prodr. Fl. Nov. Holland. 228, 1810. -TYPE: Australia, Queensland. R. Br. 5960 (holotype: BM, photo!). 
Scirpus sericeus (R. Br.) Poir., Encycl., Suppl. 5: 99, 1817. 국명: 털잎하늘지기.

짧은 지하경이 있는 다년초, 식물체에 털이 많으며, 가지 끝에 3-5개씩 모여달리는 소수는 장타원상 난형으로 길이 6.7-13.5 mm, 너비 3.1-3.9 mm로 10 개 이상의 소화가 나선 상으로 돌려난다. 인편은 털이 있으며, 난형으로 반투명한 황갈색이고, 길이 2.8-3.7 mm, 나비 2.1-2.9 mm로 끝이 미 철두이다. 수술은 2 개 또는 3 개, 약은 황색으로 길이 $1.5-$ $1.8 \mathrm{~mm}$ 이다. 화주는 편평하게 약간 눌려있고, 기부에 돌기 같은 짧은 털이 있으며, 암술머리는 2개로 갈라진다. 수과 는 무늬와 돌기가 없고, 한편이 편평한 삼릉상 도란형으로 길이 1.4-1.5 mm, 너비 1.1-1.4 mm로 흑갈색으로 익는다.

국내분포: 전남, 전북.

국외분포: 일본, 중국, 동남아시아, 호주.

분류학적 검토: Brown (1810)이 오스트레일리아산을 근 거로 신종으로 기재하였다. 기재 이후 종의 실체에 대하 여 별다른 분류학적 이견은 없으나 Iria, Scirpus속으로 취 급된 적이 있다. 털잎하늘지기는 남부지방 건조한 바닷가 모래땅에 자라며 식물체에 털이 있어 속내 분류군과 쉽게 구별된다. 한편 바다지기 F. cymosa가 국내 분포한다는 기 록이(Lee, 1996; Lee, 1980) 있으나 국내에 자생하거나 채 집된 표본을 확인하지 못하여 분류학적 처리를 유보하였 고, 바다지기는 주 분포지가 아열대 지방으로 국내에 분 포 가능성은 낮은 것으로 판단된다.

털잎하늘지기의 과거 채집된 기록에 따라 해당 지역에 채집을 위해 방문하였으나 1-2곳을 제외하고, 자생지가 훼손되어 확인하지 못하였다. 자생지가 해안 배후사구로 일부는 개발로 인하여, 일부지역은 해안 침식으로 자생지 가 훼손되었다. 이와 같이 개발압력이 높고, 훼손 가능성 이 큰 지역에 분포하는 특성상 각별한 보호대책이 필요한 것으로 사료된다.

Fimbristylis littoralis Gaudich., Voy. Uranie, Bot. 413, 1829.

-TYPE: Indonesia, Gaudichaud s.n. (holotype: P, photo!).

Scirpus miliaceus L., Syst. Nat. ed. 10, 2: 868, 1759.

F. miliacea (L.) Vahl, Enum. Pl. 2: 267, 1805.

국명: 바람하늘지기.

모여 나는 1년초, 소수는 가지 끝에 단생하며, 구상 난형 으로 길이 2.0-3.5 mm, 너비 1.6-2.3 mm로 30개 이상의 소 화가 나선상으로 돌려난다. 인편은 난형으로 흑색을 띤 갈색이고, 길이 $1.0-1.3 \mathrm{~mm}$, 너비 $0.6-0.8 \mathrm{~mm}$ 로 둔두이다. 수술은 3 개, 약은 황색으로 길이 $0.3-0.5 \mathrm{~mm}$ 이다. 화주는 삼릉형이고 길이 0.4-0.6 mm로 털이 없으며, 암술머리는 3 개로 갈라진다. 수과에는 미세한 돌기가 있으며, 삼릉상 도란형으로 길이 $0.6-0.7 \mathrm{~mm}$, 너비 $0.3-0.5 \mathrm{~mm}$ 로 황갈색 으로 익는다.
국내분포: 전국.

국외분포: 서아시아와 유럽을 제외한 세계전역.

분류학적 검토: Gaudichaud (1829)가 인도네시아에서 채 집한 표본을 근거로 신종으로 기재하였다. Liu (1984), Zhang et al. (2010) 등은 각각 F. littoralis와 F. miliacea를 정 명과 이명으로 혼용하였고, Blake (1954), Kern (1974) 등은 F. miliacea와 F. littoralis를 별개 독립된 분류군으로 처리하 였으나, Koyama (1964), Liu (1984), Zhang et al. (2010) 등은 F. littoralis를 정명으로 F. miliacea를 이명으로 처리한 데 비해 Koyama (1961), Kral (1971), Ball et al. (2002)은 F. miliacea를 정명으로 F. littoralis를 이명으로 처리하였다. 특히 Koyama는 1961년 F. miliacea를 정명으로 1964년 F. littoralis를 정명으로 사용하였다.

F. miliacea는 Linnaeus가 기재한 Scirpus miliaceus를 근거 로 Vahl (1805)이 Fimbristylis속으로 옮겼다. F. littoralis와 F. miliacea의 혼란은 Scirpus miliaceus를 기재한 Linnaeus가 2 점의 표본을 남겼고, 2점의 표본이 각기 다른 분류군이어 서 혼란이 시작되어 전술한 바와 같이 학명에 혼란이 있 었으나 Strong (2004)의 견해에 따라 Zhang et al. (2010), Hoshino et al. (2011), Cho et al. (2016) 등 최근에는 $F$. littoralis를 사용하고 있어 이를 따랐다.

바람하늘지기는 논과 그 주변 수로 저수지 가장자리 등 축축한 지역에서 흔하게 관찰되며, 줄기 기부에 엽신이 없는 초상엽이 있고, 줄기 기부와 엽신이 강하게 납작 눌 리어 속내분류군과 뚜렷이 구별된다.

Fimbristylis pierotii Miq., Ann. Mus. Bot. Lugduno-Batavi 2: 145, 1865.-TYPE: Japan. Pierot s.n. (isotype: L, photo!). 국명: 들하늘지기.

짧은 지하경이 있는 다년초, 소수는 5-10개가 가지 끝에 단생하며, 좁은 장타원형으로 길이 $4.8-13.2 \mathrm{~mm}$, 너비 1.7$3.2 \mathrm{~mm}$ 로 6-14개의 소화가 나선상으로 돌려난다. 인편은 피침상 난형으로 짙은 갈색이고, 길이 $4.0-5.1 \mathrm{~mm}$, 너비 2.5-3.0 mm로 중륵이 짧게 돌출한다. 수술은 3개, 약은 황 색으로 길이 $1.9-2.3 \mathrm{~mm}$ 이다. 화주는 삼릉형이고 길이 2.5-3.1 mm로 털이 없으며, 암술머리는 3개로 갈라진다. 수과는 미세한 돌기가 있으며, 삼릉상 도란형으로 길이 $1.2-1.4 \mathrm{~mm}$, 너비 0.9-1.1 mm로 갈색, 황갈색으로 익는다.

국내분포: 경남, 전남.

국외분포: 네팔, 일본, 중국, 필리핀.

분류학적 검토: Miquel (1865)이 일본 큐슈에서 Pierot이 채집한 표본을 근거로 신종으로 기재하였고, Kuntze (1891)에 의해 Iria속으로 다뤼진 적이 있으나 종의 실체에 대하여 별다른 이견이 없다.

Oh and Park (1997)은 들하늘지기에 F. complanata for. exaltata 학명을 사용하였고, Lee (2006)는 들하늘지기에 $F$. complanata 학명을 사용하였다. 이후 Oh (2007)는 F. pierotii 
와 F. complanata for. exaltata 2 분류군 모두 국명을 들하늘 지기로 중복하여 사용하였는데 실체를 보지 못해 발생한 혼돈으로 판단된다. 국내에서는 개화 결실기가 6-7월로 국내 자생하는 하늘지기속중 가장 빠르고, 남부지방 건조 한 묘지와 바닷가 근처 초지에 자라며, 옆으로 기는 지하 경과 10 개 미만의 단순한 화서를 갖는다는 점에서 유사분 류군과 뚜렷이 구별된다.

Fimbristylis jindoensis J. Kim and M. Kim, Korean J. Pl. Taxon. 4: 319, 2015.-TYPE: Korea, Jindo-gun, J. H. Kim 141308 (holotype: JNU!).

국명: 진도하늘지기.

긴 지하경이 있는 다년초, 소수는 좁은 장타원형으로 길 이 4.2-7.2 mm, 너비 1.2-1.7 mm로 6-20개의 소화가 나선 상으로 돌려난다. 인편은 피침상 난형으로 갈색이고, 길 이 2.8-3.6 mm, 너비 1.6-2.5 mm로 중륵이 짧게 돌출한다. 수술은 3개, 약은 황색으로 길이 $1.1-1.5 \mathrm{~mm}$ 이다. 화주는 삼릉형이고 길이 1.6-1.8 mm로 털이 없으며, 암술머리는 3 개로 갈라진다. 수과에는 미세한 돌기가 있으며, 삼릉상 도란형으로 길이 $0.7-0.9 \mathrm{~mm}$, 너비 $0.5-0.6 \mathrm{~mm}$ 로 갈색, 황 갈색으로 익는다.

국내분포: 전남.

국외분포: 한국 특산종

분류학적 검토: $\mathrm{Kim}$ and $\mathrm{Kim}(2015 \mathrm{~b})$ 이 전라남도 진도 군에서 채집한 표본을 근거로 신종으로 기재하였다.

들하늘지기와는 지하경이 있는 점에서 유사하나 진도 하늘지기는 인편, 약, 수과 등이 들하늘지기보다 작아서 구별된다. 화서의 형태가 어른지기와 유사하나 진도하늘 지기는 식물체가 크며 지하경이 발달하고, 개화기가 7-8 월로 빠르고, 줄기단면이 타원형이며, 줄기가 단생하는 점에서 구별된다.

전라남도 진도군 3 개소의 산지습지에서 자생을 확인하 였고, 1 개소는 비교적 큰 군락을 유지하고 있으나, 그 중 2 개소는 저지대에 위치해 있어 개발압력이 높은 지역이고, 육화로 인하여 세력이 줄어들고 있어 각별한 보호대책이 수립되어야 할 것이다.

Fimbristylis diphylloides Makino in Nemeto, Fl. Jap. 1389, 1925. -TYPE: Japan, Fukui, R. Yatabe, J. Matsumura and T. Uchiyama s.n. (lectotype: TI, photo!).

국명: 검정하늘지기.

모여 나는 다년초, 엽신이 있는 잎은 영양줄기에서만 나 고, 소수는 난형으로 길이 4.2-6.2 mm, 너비 1.8-2.5 mm로 30 개 이상의 소화가 나선상으로 돌려나며, 둔두-예두이다. 인편은 난형으로 흑갈색이고, 길이 $1.4-1.8 \mathrm{~mm}$, 너비 0.9$1.1 \mathrm{~mm}$ 로 미철두이다. 수술은 2 개, 약은 황색으로 길이
0.5-0.6 mm이다. 화주는 삼릉형이고 길이 0.6-0.8 mm로 털 이 없으며, 암술머리는 2 개 또는 3 개로 갈라진다. 수과에 는 미세한 돌기가 있으며, 삼릉상 도란형, 양철형으로 길 이 0.7-0.8 mm, 너비 0.5-0.6 mm로 황갈색으로 익는다.

국내분포: 경남, 전남, 전북, 제주.

국외분포: 일본, 중국.

분류학적 검토: Makino and Nemeto (1925)가 일본산을 근거로 그 저서인 Flora Japan에 일본어로 F. diphylla 에 비 하여 포엽이 짧고, 소수가 작고, 인편이 흑색이라고만 짧 게 기록해 라틴기재와 타입표본 지정을 누락하였으나 1935년 1월 1일 이후부터 현대분류학의 식물종의 기재에 관한 규정(Melbourne Code Art. 39)이 적용되므로 합법적 이다. 이후 Tuyama (1935)가 라틴어 기재를 하였으나 역시 타입표본을 지정하지 않았고, Horiuchi (2016)가 1881년 Yatabe, Matsumura and Uchiyama 등에 의해 채집되어 동경 대학교(TI)에 보관중인 표본을 Lectotype으로 지정하였다. 본 종은 한국, 일본, 중국에 분포하며 Makino가 기재한 이 후 종의 실체에 대하여 별다른 이견이 없다.

화서 줄기 기부에 엽신이 없는 초상엽만 있고 엽신이 있 는 잎은 영양경에서 나오므로 유사종과 구별된다. 외부형 태가 물하늘지기와 유사하나 잎보다 줄기가 길고 저수지 가장자리부터 산지습지, 임도변의 축축한 곳에 자라며, 인편이 흑갈색, 암술머리가 2-3개로 갈라지고, 수술이 2 개이며, 화주가 0.6-0.8 mm로 작아서 물하늘지기와 구별 된다.

Fimbristylis drizae J. Kim and M. Kim, Korean J. Pl. Taxon. 45: 9, 2015.-TYPE: Korea. J. H. Kim 13158 (holotype: JNU!) 국명: 물하늘지기.

모여 나는 다년초, 엽신이 있는 잎은 영양줄기에서만 나 고, 소수는 타원형-난상 타원형으로 길이 $2.9-5.8 \mathrm{~mm}$, 너 비 1.7-2.9 mm로 30 개 이상의 소화가 나선상으로 돌려나 며, 둔두-원두이다. 인편은 난형으로 황갈색이고, 길이 1.7-2.2 mm, 너비 0.9-1.2 mm로 가장자리는 막질이고, 중 륵은 녹색으로 3 맥이 있고, 미철두이다. 수술은 1 개 드물 게 2개, 약은 황색으로 길이 $0.5-0.7 \mathrm{~mm}$ 이다. 화주는 삼릉 형이고 길이 0.8-1.2 mm로 털이 없으며, 암술머리는 2개로 갈라진다. 수과에는 미세한 돌기가 있으며, 도란상 둔한 삼릉형 양철형으로 길이 $0.6-0.9 \mathrm{~mm}$, 너비 $0.5-0.6 \mathrm{~mm}$ 로 황갈색으로 익는다.

국내분포: 경남, 경북, 전남, 전북, 충남, 충북.

국외분포: 한국 특산종

분류학적 검토: $\operatorname{Kim}$ and $\operatorname{Kim}$ (2015a)이 전라북도 정읍시 에서 채집한 표본을 근거로 신종으로 기재하였다. 물하늘 지기는 외부형태가 검정하늘지기와 유사하게 줄기 기부 에 엽신이 없는 초상엽만 달리고, 엽신이 있는 잎은 영양 경에서만 나온다. 물하늘지기는 검정하늘지기에 비하여 
엽신이 있는 잎이 줄기보다 길고, 화주 길이가 $0.8-1.2 \mathrm{~mm}$ 로 0.6-0.8 mm인 검정하늘지기보다 길다. 또한, 소수가 타 원형-난상 장타원형으로 원두-둔두이고, 인편이 황갈색 인 점에서 구별된다. 물하늘지기는 생육지에서 검정하늘 지기의 인편이 흑갈색이므로 서식지와 외부형태의 차이 로 쉽게 구별된다.

한국에 분포하는 것으로 알려진 둥근하늘지기 $F$. globulosa var. austrojaponica는 기준표본과 기재문을 확인 한 결과 열대지방에 분포하는 F. umbellaris와 같은 분류군 으로 판단되고, Zhang et al. (2010)도 F. umbellaris의 이명으 로 처리하였다. 국내에 채집되어 둥근하늘지기로 보관중 인 표본 관찰결과 F. umbellaris로 판단되는 표본은 없었고 물하늘지기만 있었다. 물하늘지기는 검정하늘지기와 유 사하나 수술 개수, 암술머리 갈라진 개수, 화주 길이, 인편 의 색, 줄기보다 긴 잎 등에서 차이를 보여 신종으로 처리 한 견해를 따랐다.

Fimbristylis complanata var. exaltata (T. Koyama) Y. C. Tang ex S. R. Zhang and T. Koyama, Fl. China 23: 205, 2010. -TYPE: Japan, Honshu. J. Ohwi 7557 (holotype: KYO).

F. complanata for. exaltata T. Koyama, Bull. Arts Sci. Div. Ryukyu Univ. 3: 70, 1959.

국명: 어른지기.

모여 나는 다년초, 소수는 좁은 장타원형으로 길이 4.4$9.6 \mathrm{~mm}$, 너비 1.2-1.6 mm로 8-20개의 소화가 나선상으로 돌려난다. 인편은 피침상 난형으로 갈색이고, 길이 2.2-3.2 $\mathrm{mm}$, 너비 1.1-1.4 mm으로 중륵이 짧게 돌출한다. 수술은 3 개, 약은 황색으로 길이 $1.2-1.6 \mathrm{~mm}$ 이다. 화주는 삼릉형이 고 길이 1.4-1.7 mm로 털이 없으며, 암술머리는 3개로 갈 라진다. 수과에는 미세한 돌기가 있으며, 삼릉상 도란형 으로 길이 $0.7-0.8 \mathrm{~mm}$, 너비 $0.4-0.5 \mathrm{~mm}$ 로 흰색, 황백색으 로 익는다.

국내분포: 경기, 경남, 경북, 전남, 전북, 제주, 충남.

국외분포: 대만, 일본, 중국.

분류학적 검토: Koyama (1959)가 일본에서 Ohwi가 채집 한 것을 근거로 F. complanata for. exaltata로 품종으로 발표 하였다. 이후 Zhang et al. (2010)가 var. exaltata로 변종으로 처리하였고, Deng (2011)은 F. exaltata로 독립된 종으로 처 리하였다. 열대지방에 자라는 원변종은 식물체가 크며, 짧게 기는 지하경이 있고, 잎도 넓다. 어른지기는 원변종 에 비하여 한국, 일본, 중국 등 온대에 자라며, 식물체가 작 고, 잎이 가늘고, 근경이 짧아 빽빽하게 모여 나는 것이 다 르나 소수, 인편, 수과 등에서 뚜렷한 차이가 없어 변종으 로 처리한 견해에 따랐다.

외부형태가 애기하늘지기와 유사하나 일년생인 애기 하늘지기에 비하여 다년생이며 산지 습지인 자생지, 약의 개수와 길이, 인편과 암술이 커서 뚜렷이 구별되었다.
Fimbristylis autumnalis (L.) Roem. and Schult., Syst. Veg. 2: 97, 1817.-TYPE: USA, Virginia, Clayt. 772 (holotype: BM, photo!).

Scirpus autumnalis L., Mant. Pl. Alt. 2: 180, 1771.

국명: 애기하늘지기.

모여 나는 1년초, 소수는 좁은 장타원형으로 길이 3.8$6.5 \mathrm{~mm}$, 너비 $1.0-2.2 \mathrm{~mm}$ 로 7-20개의 소화가 나선상으로 돌려난다. 인편은 피침상 난형으로 밝은 갈색이고, 길이 1.6-2.1 mm, 너비 1.0-1.1 mm로 중륵이 짧게 돌출해 밖으 로 휘어진다. 수술은 1-2개, 약은 황색으로 길이 $0.3-$ $0.5 \mathrm{~mm}$ 이다. 화주는 삼릉형이고 길이 $0.7-0.9 \mathrm{~mm}$ 털이 없 으며, 암술머리는 3 개로 갈라진다. 수과는 미세한 돌기가 없거나 있으며, 삼릉이 뚜렷한 도란형으로 길이 0.6$0.8 \mathrm{~mm}$, 너비 0.4-0.6 mm로 흰색, 황백색으로 익는다.

국내분포: 전국.

국외분포: 일본, 중국, 동남아시아, 남아메리카, 북아메 리카.

분류학적 검토: Linnaeus (1771)가 미국에서 Clayton이 채집한 것을 근거로 Scirpus autumnalis로 기재하였으나 Roemer and Schultes (1817)가 Fimbristylis속으로 이속하였 고, Iria, Isolepis, Trichelostylis속으로 취급되기도 했으나, 종의 실체에 대한 분류학적 이견이 없다.

외부형태가 어른지기와 유사하므로 국내 관찰표본에 서 어른지기와 애기하늘지기가 섞여있어 오동정이 높은 분류군이다. 다년생으로 외부형태가 유사한 어른지기와 는 일년생으로 생활형이 다르고, 주로 경작지, 저수지 가 장자리와 같이 교란된 환경에 분포하는 애기하늘지기와 달리 어른지기는 산지 습지에 분포하므로 서식지로 구별 된다. 또한, 애기하늘지기는 약이 $0.5 \mathrm{~mm}$ 미만, 화주 길이 가 $1.0 \mathrm{~mm}$ 미만인데 비해 어른지기는 약이 $1.0 \mathrm{~mm}$ 이상, 회주 길이가 $1.0 \mathrm{~mm}$ 이상으로 커서 쉽게 구별되었다.

\section{고 찰}

한국에 분포하는 하늘지기속(Fimbristylis) 21 분류군에 대하여 형태학적인 연구를 진행한 결과 화서의 형태, 줄 기 기부의 초상엽 유무, 지하경의 발달유무, 암술머리의 갈라진 개수, 수술의 개수와 길이 등이 기존에 알려진 식 별형질이었으나(Ohwi, 1944; Kern, 1974; Ball et al., 2002; Zhang et al., 2010), 이번 연구에서 화주의 길이와 약의 길 이의 차이점이 유사 분류군 간의 유용한 식별형질로 확인 되었다.

푸른하늘지기(F. dipsacea (Rottbøll) C. B. Clarke var. verrucifera (Maximowicz) T. Koyama)는 열대지방에 자라는 원변종 F. dipsacea와 인편에 까락이 거의 없는 점에서 차이 만 있어 변종으로 처리한 Koyama (1961)의 견해를 따랐다.

암하늘지기(F. squarrosa var. esquarrosa Makino)는 
Makino (1903)가 변종으로 기재하였으나 종으로 취급할 경우 Brown (1810)에 의해 발표된 F. velata를 쓰는 것이 적 법하고, 변종으로 취급 할 경우 var. esquarrosa가 정당명이 다. 민하늘지기와 인편 이외 차이가 없어 변종으로 발표 한 Makino (1903) 견해를 따랐다.

꼴하늘지기(F. subbispicata Nees and Meyen)는 Koyama (1961)가 꼴하늘지기를 F. tristachya var. subbispicata로 변 종으로 취급하였다. 꼴하늘지기는 소수가 단생하는 것이 특징적이며, 아열대지방에 분포하는 F. tristachya와 유사 하나 소수의 개수가 최대 11 개까지 달리므로 분포지와 소 수의 개수에서 차이를 보여 독립된 종으로 처리된 견해를 따랐다.

갯하늘지기(F. sieboldii Miquel ex Franchet and Savatier)는 Ohwi (1938)가 아열대 지방에 자라는 F. ferrugineae의 변종 var. sieboldii로 처리하였으나 F. ferrugineae와는 약의 크기 와 화주의 길이가 달라서 독립된 종으로 처리한 견해를 따랐다.

털하늘지기(F. tomentosa Vahl)는 Ohwi (1938)가 F. dichotoma f. tomentosa로 품종으로 처리하였고, Koyama (1964)는 F. dichotoma subsp. podocarpa의 이명으로, Zhang et al. (2010)은 F. dichotoma의 이명으로 처리하였다. 하늘 지기와 외부형태가 유사하나 털하늘지기는 수과 표면의 격자무늬가 11-20줄이고, 약의 길이가 0.6-0.6 mm로 하늘 지기와 차이를 보여 독립된 종으로 처리한 견해를 따랐다.

하늘지기(F. dichotoma L. var. dichotoma)는 Koyama (1988)가 동북아에 분포하는 것이 1년생이라는 점을 들어 한국, 일본, 중국에 분포하는 종을 var. tentsuki로 신변종으 로 처리하였으나 아열대 지방에서도 건기에 말라죽는 것 이 있으므로 var. tentsuki는 의미가 없는 것으로 판단된다. 가는하늘지기로 알려진 f. depauperata는 기준산지가 호주 이며 분포지가 남태평양으로 국내에는 분포하지 않는 것 으로 판단된다.

남하늘지기(F. dichotoma var. floribunda Miq.)는 Ohwi(1938)가 F. dichotoma for. floribunda로 하늘지기의 품 종으로 옮겼고, Koyama (1988)는 F. dichotoma var. floribunda로 변종으로 처리하였다. 바닷가 근처의 건조한 초지에 자라며 다년생으로 근경이 뚜렷하게 관찰되어 변 종으로 처리한 Koyama (1988)의 견해를 따랐다.

바람하늘지기(F. littoralis Gaudich.)는 그동안 국내외 학 자들이 F. littoralis와 F. miliacea의 학명을 혼용하여 사용해 왔으나 Strong (2004)의 견해에 따라 Zhang et al. (2010), Hoshino et al. (2011), Cho et al. (2016) 등이 최근에 $F$. littoralis의 학명을 사용하고 있어 이를 따랐다.

물하늘지기(F. drizae J. Kim and M. Kim)는 검정하늘지 기와 유사하나 저수지 만수위선 근처에서만 관찰되고, 잎 이 줄기보다 길며 화주가 검정하늘지기보다 길어 독립된 종으로 처리한 견해에 따랐다.

들하늘지기(F. pierotii Miq.)는 Oh and Park (1997)이 들하
늘지기에 F. complanata for exaltata 학명을 사용하였고, Lee (2006)는 들하늘지기에 F. complanata 학명을 사용하였 다. 이후 Oh (2007)는 F. pierotii와 F. complanata for. exaltata 2 분류군 모두 국명을 들하늘지기로 중복하여 사용하였는 데 이는 개화기가 빠른 들하늘지기의 특징으로 채집된 표 본이 없어 혼돈한 것으로 판단된다. 들하늘지기는 지하경 이 있고 줄기가 단생하는 점에서 진도하늘지기와 유사하 나 소수가 4-8개로 단순한 화서로 구별되었다.

밭하늘지기, 좀민하늘지기, 민하늘지기, 큰하늘지기, 진도하늘지기, 털잎하늘지기, 검정하늘지기, 어른지기, 애기하늘지기는 종의 실체에 관하여 특별한 논란이 없다.

한국산 하늘지기속에 대하여 Oh (1991)는 수과의 형태 로 하늘지기절(sect. Fimbristylis)과 밭하늘지기절(sect. Mischospora, Fimbristylis)로 분류하였다. 소수에 인편이 돌 려나는 분류군과 달리 소수가 약간 눌려 마주나는 쇠하늘 지기는 쇠하늘지기절(sect. Abildgaardia)로 구별하는 것이 자연스럽고, 수과가 원통형인 특징으로 구분된 밭하늘지 기절(sect. Mischospora)과 달리 하늘지기절에 속한 분류군 의 수과 형태가 양철형과 삼릉형으로 구별되는바 양철형 은 하늘지기절(sect. Fimbristylis), 삼릉형은 애기하늘지기 절(sect. Trichelostylis)로 구분하는 것이 타당할 것이다.

2012년부터 2017년까지 한국산 하늘지기속에 대한 분 류학적 연구를 종합적으로 수행한 결과 그동안 식별 형질 로 유용하다고 알려지지 않은 약의 길이와 화주의 길이가 유사분류군간 식별 형질로 유용한 것으로 나타났으며, 한 국산 하늘지기속 식물은 4 개절(sect.) 19 종 2 변종 총 21 분 류군으로 확인되었다. 금회 연구에서 채집하지 못하여 제 외된 제주하늘지기와 바다지기를 포함하여 추가적인 형 태학적 연구가 진행되어야 할 것이다.

\section{Acknowledgments}

The authors thank the anonymous reviewers for their valuable comments and suggestions.

\section{Conflict of Interest}

The authors declare that there are no conflicts of interest.

\section{Literature Cited}

Ball, P. W., A. A. Reznicek and D. F. Murray. 2002. Cyperaceae. In Flora of North America, Vol. 23. Magnoliophyta: Commelinidae (in part): Cyperaceae. Flora of North America Editorial Committee (ed.), Oxford University Press, New York. Pp. 3-8.

Bentham, G. 1878. Flora Australiensis: a Description of the Plants of the Australian Territory, by George Bentham, Assisted by 
Ferdinand Mueller. Vol. 7. L. Reeve, London. Pp. 298-322.

Blake, S. T. 1954. The Cyperaceae collected in New Guinea. Journal of the Arnold Arboretum 35: 203-238.

Böeckeler, O. 1871. Die Cyperaceen des Königlichen Herbarium zu Berlin. Linnaea 37: 2-51.

Brown, R. 1810. Prodromus florae Novae Hollandiae et Insulae Van-Diemen exhibens characters plantarum quas annis 18021805 per oras utriusque insulae collegit et descripsit Robertus Brown; insertis passim aliis speciebus auctori hucusque cognitis, seu evulgatis, seu ineditis, praæsertim Banksianis, in primo itinere navarchi Cook detectis, Vol. 1. R. Taylor, Londini. Pp. 226-229.

Burman, N. L. 1768. Flora Indica: cui accedit series zoophytorum Indicorum, nec non prodromus florae Capensis. Apud Cornelium Haek, Amstelaedami. P. 194.

Cho, Y. H., J. H. Kim and S. H. Park. 2016. Grasses and Sedges in South Korea. Geobook, Seoul. Pp. 337-354. (in Korean)

Chung, T. H., B. S. Do, D. B. Lee and H. J. Lee. 1937. Choseon Plant Name Collection. Society for Choseon Natural History Research. P. 25. (in Korean)

Debeaux, J. O. and A. R. Franchet. 1877. Societe Linneenne de Bordeaux 32: 36-39.

Deng, Y. F. 2011. Cyperaceae. In Flora of Hong Kong, Vol. 4. Hu, Q. -M. and D.-L. Wu (eds.), Hong Kong Herbarium, Agriculture, Fisheies and Conservation Department, Hong Kong. Pp. 98.

Franchet, A. and L. Savatier. 1877. Enumeratio plantarum: in Japonia sponte crescentium hucusque rite cognitarum, adjectis descriptionibus specierum pro regione novarum, quibus accedit determinatio herbarum in libris japonicis So mokou zoussetz xylographice delineatarum, Vol. 2. F. Savy, Parisiis. Pp. 117-120.

Gaudichaud, B. C. 1829. Voyage autour du monde, entrepris par ordre du roi, éxécuté sur les corvettes de S. M. l'Uranie et la Physicienne, pendant les annees 1817, 1818, 1819 et 1820. Botanique 413.

Govaerts, R. 2010. Fimbristylis World Checklist of Selected Plant Families, the Royal Botanic Gardens, Kew. Retrieved Mar. 14, 2017, available from http://apps.kew.org/wcsp/

Govaerts, R. and D. A. Simpson. 2007. World Checklist of Cyperaceae, Sedges. Royal Botanical Garden, Kew, 765 pp.

Hasskarl, J. C. 1848. Plantae Javanicae Rariores 61. Berlin, 554 pp.

Horiuchi, H. 2016. Lectotypification of Fimbristylis diphylloides (Cyperaceae). The Journal of Japanese Botany 91: 305-307.

Hoshino T., T. Masaki and M. Nishimoto. 2011. Illustrated Sedges of Japan. Heibonsha Ltd., Tokyo. Pp. 572-608. (in Japanese)

Im, R. J. 2000. Flora Coreana, Vol. 9. The Science and Technology Publishing House, Pyongyang, North Korea.
Kern, J. H. 1967. A new combination in Fimbristylis (Cyperaceae). Blumea 15: 126.

Kern, J. H. 1974. Fimbristylis. In Flora Malesiana, Ser. 1. Vol. 7. Part 3. van Steenis, C. G. G. J. (ed.), Noordhoff Int. Pub., Leiden. Pp. 540-592.

Kim, J. H. and M. Kim. 2013. First record of Fimbristylis hookeriana Boeckeler (Cyperaceae) from Korea. Korean Journal of Plant Taxonomy 43: 296-299. (in Korean)

Kim, J. and M. Kim. 2015a. A new species of Fimbristylis (Cyperaceae): F. drizae J. Kim and M. Kim. Korean Journal of Plant Taxonomy 45: 8-11. (in Korean)

Kim, J. and M. Kim. 2015b. A new species of Fimbristylis (Cyperaceae): F. jindoensis J. Kim and M. Kim. Korean Journal of Plant Taxonomy 45: 318-322. (in Korean)

Koyama, T. 1959. Taxonomic study of Cyperaceae 9. Bulletin of Arts and Science Division, Ryukyu University 3: 65-71.

Koyama, T. 1961. Classification of the Cyperaceae (1). Journal of the Faculty of Science, University of Tokyo, Sect. 3, Botany 8: 99-119.

Koyama, T. 1964. The Cyperaceae of Micronesia. Micronesica 1: 80-91.

Koyama, T. 1988. Variations of Fimbristylis dichotoma (L.) Vahl (Cyperaceae) in Japan. Journal of Japanese Botany 63: 86-95.

Kral, R. 1971. A treatment of Abildgaardia, Bulbostylis and Fimbristylis (Cyperaceae) for North America. Sida 4: 57-227.

Kuntze, O. 1891. Revisio generum plantarum:vascularium omnium atque cellularium multarum secundum leges nomenclaturae internationales cum enumeratione plantarum exoticarum in itinere mundi collectarum, Vol. 2. A. Felix, Leipzig. Pp. 751-752.

Kuoh, C. S. 1977. Note on the morphology and geographical distribution of Formosan Fimbristylis (Cyperaceae). Biological Bulletin Taiwan Normal University 12: 79-88.

Lee, T. B. 1980. Illustrated Flora of Korea. Hyangmunsa, Seoul, 990 pp. (in Korean)

Lee, W. T. 1996. Lineamenta Florae Koreae. Academy Press, Seoul, 1688 pp. (in Korean)

Lee, Y. N. 2006. New Flora of Korea. Kyohaksa, Seoul, 975 pp. (in Korean)

Linnaeus, C. 1753. Species Plantarum 1:50

Linnaeus, C. 1767 (-1771). Car. a Linné Mantissa plantarum: Generum editionis VI. et specierum editionis II. Salvii, Homiae. Pp. 180-181.

Liu, H. Y. 1984. Fimbristylis. In Flora of Taiwan. 2nd ed. Vol. 5. Taiwan Department of Botany (ed.), Deparement of Botany, National Taiwan University, Taipei. Pp. 261-281.

Makino, T. 1895. Commentary (雜錄) Botanical Magazine, Tokyo 9: 259. 
Makino, T. 1903. Observations on the flora of Japan. Botanical Magazine, Tokyo 17: 47.

Makino, T. and K. Nemoto. 1925. Flora Japan. Fimbristylis. Kankôkai, Tokyo, 1389 pp.

Maximowicz, C. J. 1859. Primitiae florae Amurensis. Mémoires présentés à l'Académie Impériale des Sciences de St. Petersbourg par divers Savans et dans ses Assemblees (Primitiae Florae Amurensis) 9: 1-504.

Miquel, F. A. G. 1865. Anonaceae Archipelagi Indici. Annales Musei Botanici Lugduno-Batavi 2:1-44.

Miquel, F. A. G. 1870. Catalogus Musei Botanici Lugduno-Batavi. Digessit F.A. Guil Miquel. Pars prima, Flora Japonica. Martinum Nijhoff, The Hague. P. 118.

Nakai, T. 1909. Flora Koreana I. Journal of the College Science, Imperial University of Tokyo 26: 1-304.

Nakai, T. A. 1952. Synoptical sketch of Korean Flora. Bulletin of the National Science Museum 31: 1-152.

Nees, C. G. and F. J. Meyen. 1843. Cyperaceae. Novorum Actorum Academiae Caesareae Leopoldinae-Carolinae Naturae Curiosorum 29 (Suppl. 1): Pp. 53-124.

Oh, Y. C. 1991. Leaf epidermal patterns of Korean sedge taxa characterized by SEM and LM (IV. Fimbristylis). Korean Journal of Plant Taxonomy 21: 83-94. (in Korean)

Oh, Y. C. 2000. Cyperaceae in Korea. Sungshin Womens University Press, Seoul Pp. 121-162.

Oh, Y. C. 2007. Cyperaceae. In Genera of Vascular Plants of Korea. Park, C. W. (ed.), Academy Publishing Co., Seoul. Pp. 1126-1131.

Oh, Y. C. and J. M. Park. 1997. A taxonomic study on Fimbristylis Vahl of Korea (Cyperaceae). Korean Journal of Plant Tax- onomy 27: 429-455. (in Korean)

Ohwi, J. 1938. Notes on Japanese Fimbristylis. Journal of Japanese Botany 14: 564-579.

Ohwi, J. 1944. Cyperaceae Japonicae II. A synopsis of the Rhynchosporotdeae and Scirpoideae of Japan including the Kuriles, Saghalin, Korea, and Formosa. Memoirs of the College of Science, Kyoto Imperial University, Series B, Biology 11: 5286.

Retzii, A. I. 1786. Observationes Botanicae 4: 12.

Retzii, A. I. 1789. Observationes Botanicae 5: 14.

Roemer, J. J and J. A. Schultes. 1817. Caroli a Linné Systema vegetabilium: secundum classes, ordines, genera, species. Cum characteribus, differentiis et synonymiis. Vol. 2. Sumtibus J.G. Cottae, Stuttgardtiae. Pp. 91-105.

Steudel, E. G. V. 1855. Synopsis Plantarum Glumacearum, Vol. 2. J.B. Metzler, Stuttgart. Pp. 106-121.

Strong, M. T. 2004. Proposal to reject the name Scirpus miliaceus (Cyperaceae). Taxon 53: 1069-1070.

Tang, T. and F. T. Wang. 1961. Fimbristylis. In Flora of China, Vol. 11. Oxalidaceae through Aceraceae. Wu, Z. Y., P. H. Raven and D. Y. Hong (eds.), Science Press, Beijing and Missouri Botanical Garden Press, St. Louis, MO. Pp. 72-108.

Tuyama, T. 1935. Notes on Japanese species of the genus Fimbristylis (1). Journal of Japanese Botany 11: 252-254.

Vahl, M. 1805. Fimbristylis. Enumeratio Plantarum 1: 285-295.

Zhang, S., S. Liang, T. Koyama, G. C. Tucker and D. A. Simpson. 2010. Fimbristylis. In Flora of China, Vol. 23. Acoraceae through Cyperaceae. Wu, Z. Y., P. H. Raven and D. Y. Hong (eds.), Science Press, Beijing and Missouri Botanical Garden Press, St. Louis, MO. Pp. 200-218.

\title{
한국산 하늘지기속(사초과)의 분류학적 연구
}

\author{
김종환 - 김무열* \\ 전북대학교 자연과학대학 생명과학과
}

적 요: 한국에 분포하는 사초과의 하늘지기속(Fimbristylis Vahl) 식물들에 대해 외부 형태학적 측면에서 종 합적으로 연구한 결과 그동안 식별형질로서의 중요성을 인정받지 못했던 약의 크기나 화주의 길이가 유사분 류군간의 식별형질로 유의미한 것으로 판명되었다. 국내 문헌에 기록은 있으나 국내 표본관에 채집표본이 없어 한국 내 자생 여부가 불명확했던 쇠하늘지기 Fimbristylis ovata (Burm.f.) J. Kern가 제주도 마라도 초지 에 생육하는 것이 확인되었다. 따라서 한국산 하늘지기속 식물은 4 개절 $(\mathrm{sect})$ 로 구분되며, 19종 2 변종으로 총 21 분류군으로 확인되었다.

주요어: 하늘지기속, 분류학적 연구, 사초과, 방동사니아과 
Appendix 1. Examined specimens of Fimbristylis species in Korea.

Fimbristylis ovata (Burm.f.) J. Kern 쇠하늘지기

KOREA. Jeju-do: Seogwipo-si, 17 Aug 2017, J. H. Kim 174384, J. H. Kim 174386, J. H. Kim 174393 (JNU).

Fimbristylis dipsacea (Rottb.) C. B. Clarke var. verrucifera (Maxim.) T. Koyama 푸른하늘지기

KOREA. Busan-si: Gijang-gun, 18 Jun 2015, J. H. Kim 152159, J. H. Kim 152160 (JNU); Jeollanam-do: Gangjin-gun, 19 Aug 2012 , J. H. Kim 1204 (JNU); Jeollabuk-do: Jeongeup-si, 28 Sep 2013, J. H Kim 1313, J. H. Kim 13140, J. H. Kim 13147, J. H. Kim 13148 (JNU); 18 Sep 2015, J. H. Kim 152527, J. H. Kim 152530 (JNU); Gunsan-si, 23 Sep 2015, J. H. Kim 152585 (JNU).

Fimbristylis stauntonii Debeaux and Meyen 밭하늘지기

KOREA. Chungcheongbuk-do: Danyang-gun, $30 \mathrm{Jul}$ 2012, J. H. Kim 12137, J. H. Kim 12138, J. H. Kim 12141, J. H. Kim 12144, J. H. Kim 12149, J. H. Kim 12150 (JNU); Gyeongsangnam-do: Changnyeong-gun, 6 Oct 2013, J. H. Kim 13079-J. H. Kim 13081 (JNU); Jeollanam-do: Yeonggwang-gun, 31 Aug 2013, J. H. Kim 152600 (JNU).

Fimbristylis sericea (Poir) R. Br. 털잎하늘지기

KOREA. Jeollanam-do: Sinan-gun, 2 Nov 2006, J. H. Kim 233; 29 Aug 1997, H. T. Im 49621; 2 Sep 2005, H. B. Shim and S. G. Kwon 3085 (KB); Wando-gun, 16 Oct 2010, J. H. Kim 1877 (KB); 16 Sep 2014, J. H. Kim 141483, J. H. Kim 141484; Jeollabuk-do: Gochang-gun, 9 Aug 2008, J. H. Kim 673 (KB); 9 Sep 2014, J. H. Kim 141436, J. H. Kim 141438, J. H. Kim 141441 (JNU).

Fimbristylis aestivalis (Retz.) Vahl 좀민하늘지기

KOREA. Chungcheongnam-do: Nonsan-si, 2 Oct 2015, J. H. Kim 152627 (JNU); Gangwon-do: Yangyang-gun, 6 Jun 2013, J. H. Kim 13090 (JNU); Gyeongsangbuk-do: Munkyung-si, 3 Oct 2015, J. H. Kim 152650, J. H. Kim 152652 (JNU); Gwangju-si: Dong-gu, 23 Aug 2015, J. H. Kim 152413 (JNU); Jeollanam-do: Jangseong-gun, 13 Oct 2012, J. H. Kim 12130 (JNU); Hwasun-gun, 12 Sep 2015, J. H. Kim 152511 (JNU); Jeollabuk-do: Jeongeup-si, 28 Sep 2013, J. H. Kim 13136, J. H. Kim 13154 (JNU); Lmsil-gun, 8 Aug 2013, J. H. Kim 13056 (JNU).

Fimbristylis squarrosa Vahl var. squarrosa 민하늘지기

KOREA. Busan-si: Gijang-gun, 23 Aug 2015, J. H. Kim 152410 (JNU); Chungcheongnam-do: Nonsan-si, 2 Oct 2015, J. H. Kim 152526 (JNU); Gangwon-do: Chuncheon-si, 29 Sep 2014, J. H. Kim 141626 (JNU); Jeollanam-do: Hwasun-gun, 12 Sep 2015, J. H. Kim 152513 (JNU); Gwangyang-si, 7 Oct 2014, J. H. Kim 141704 (JNU); Jeollabuk-do: Jeongeup-si, 28 Sep 2013, J. H. Kim 13134, J. H. Kim 13152 (JNU); 29 Jul 2014, J. H. Kim 141323 (JNU); 18 Sep 2015, J. H. Kim 152524 (JNU).

Fimbristylis squarrosa Vahl var. esquarrosa Makino 암하늘지기

KOREA. Busan-si: Gijang-gun, 18 Jun 2015, J. H. Kim 152165, J. H. Kim 152171 (JNU); Jeollabuk-do: Jeongeup-si, 28 Sep 2013, J. H. Kim 13156; 18 Sep 2015, J. H. Kim 152522, J. H. Kim 152523 (JNU); Gochang-gun, 17 Jun 2014, J. H. Kim 141112, J. H Kim 141165, J. H. Kim 152091 (JNU); Jeollanam-do: Yeonggwang-gun, 29 Sep 2015, J. H. Kim 152608, J. H. Kim 152609 (JNU).

Fimbristylis subbispicata Nees and Meyen 꼴하늘지기

KOREA. Gangwon-do: Goseong-gun, 10 Aug 2012, J. H. Kim 12062 (JNU); Gyeongsangnam-do: Geoje-si, 2 Sep 2012, J. H. Kim 12041 (JNU); Namhae-gun, 27 Jul 2013, J. H. Kim 13009 (JNU); Jeju-do: Seogwipo-si, 19-21 Aug 2015, J. H. Kim 152362 (JNU); Jeollanam-do: Suncheon, 1 Oct 2012, J. H. Kim 12090 (JNU); Sinan-gun, 9 Sep 2012, J. H. Kim 12006 (JNU); Jangseong-gun, 1 Aug 2013, J. H. Kim 13002 (JNU); Wando-gun, 19 Jul 2013, J. H. Kim 13013 (JNU); Jindo-gun, 22 Jul 2014, J. H. Kim 141295 (JNU); Jeollabuk-do: Jeonju-si, 11 Sep 2015, J. H. Kim 152491 (JNU).

Fimbristylis hookeriana Boeck. 바위하늘지기

KOREA. Jeollanam-do: Yeonggwang-gun, 22 Sep 2013, J. H. Kim 13162, J. H. Kim 13163 (JNU); Hwasun-gun, sn. Oct 2015, H. J. Na s.n. (JNU); Jindo-gun, 10 Oct 2015, J. H. Kim 152712 (JNU); Wando-gun, 11 Aug 2013, J. H. Kim 131337, J. H. Kim 131339 (JNU); 9 Oct 2015, J. H. Kim 152681, J. H. Kim 152682 (JNU); Jeollabuk-do: Gunsan-si, 9 Nov 2012, J. H. Kim 12133, J. H. Kim 12134 (JNU)

Fimbristylis sieboldii Miq. ex Franch. and Sav. 갯하늘지기

KOREA. Chungcheongnam-do: Taean-gun, 29 Aug 2015, J. H. Kim 152426 (JNU); Boreong-gun, 30 Aug 2015, J. H. Kim 152450 (JNU); Gyeongsangnam-do: Hadong-gun, 12 Sep 2012, J. H. Kim 12080 (JNU); 6 Aug 2013, J. H. Kim 13045 (JNU); Jeju-do: Jeju-si, 5 May 2014, J. H. Kim 140977 (JNU); Seogwipo-si, 19-21 Aug 2015, J. H. Kim 152377 (JNU); Jeollanam-do: Wando-gun, 1 Oct 2013, J. H. Kim 13088 (JNU); Sinan-gun, 4 Jul 2015, J. H. Kim 152221 (JNU); Jeollabuk-do: Buan-gun, 1-2 Aug 2015, J. H. Kim 1522897 (JNU); Ulsan-si: Bukgu, 6 Jun 2014, J. H. Kim 141237 (JNU).

Fimbristylis longispica Steud. 큰하늘지기

KOREA. Gyeonggi-do: Iansan-si, 20 Aug 2016, J. H. Kim 163689, J. H. Kim 163691, J. H. Kim 163694, J. H. Kim 163698, J. H. Kim 163700 (JNU); Jeju-do: Jeju-si, 25 Aug 2009, CJ 16 (KB); Jeollanam-do: Hampyeong-gun, 6 Aug 2006, KJH 373 (KB); Jindo-gun, 6 Aug 2010, Im 50448 (KB); Goheunggun, 13 Sep 2010, Im 51285 (KB); Yeonggwang-gun, 25 Sep 2010, Kim 110813 (KB). 
Fimbristylis tomentosa Vahl 털 하늘지기

KOREA. Jeollanam-do: Sinan-gun, 8 Sep 2013, J. H. Kim 13062; 11 Sep 2016, J. H. Kim 163799 (JNU); Jindo-gun, 1 Sep 2013, J. H. Kim 13096, J. H. Kim 13103-5 (JNU); 31 Aug 2013, J. H. Kim 13101, J. H. Kim 13102 (JNU); 10 Sep 2016, J. H. Kim 163799, J. H. Kim 163819 (JNU).

Fimbristylis dichotoma (L.) Vahl var. dichotoma 하늘지기

KOREA. Gyeongsangnam-do: Hamyang-gun, 17 Aug 2014, J. H. Kim 141368 (JNU); Gyeongsangbuk-do: Gimcheon-si, 20 Sep 2015 , J. H. Kim 152572 (JNU); Incheon-si: Jun-gu, 22 Sep 2012, J. H. Kim 12063 (JNU); Jeollanam-do: Sinan-gun, 9 Sep 2012, J. H. Kim 12001 (JNU); Hampyeong-gun, 9 Sep 2012, J. H. Kim 12012 (JNU); Hwasun-gun, 12 Sep 2015, J. H. Kim 152493 (JNU); Jeollabuk-do: Namwonsi, 5 Sep 2012, J. H. Kim 12032 (JNU); Jangsu-si, 8 Sep 2015, J. H. Kim 152482 (JNU), Wanju-gun, 13 Sep 2013, J. H. Kim 13116 (JNU); Gimje-si, 16 Jul 2015, J. H. Kim 152230 (JNU).

Fimbristylis dichotoma (L.) Vahl var. floribunda (Miq.) Ohwi 남하늘지기

KOREA. Jeollanam-do: Jindo-gun, 29 Jul 2016, J. H. Kim 163615 (JNU); 3 Sep 2016, J. H. Kim 163782, J. H. Kim 163789 (JNU); Jejudo: Seogwipo-si, 26 Sep 2014, J. H. Kim 141592, J. H. Kim 141593, J. H. Kim 141595 (JNU); Jeju-si, 25 Sep 2014, J. H. Kim 141530, J. H. Kim 141532-J. H. Kim 141534 (JNU).

Fimbristylis littoralis Gaudich 바람하늘지기

KOREA. Gyeongsangnam-do: Geoje-si, 2 Sep 2012, J. H. Kim 12040 (JNU); Changnyeong-gun, 6 Oct 2013, J. H. Kim 13083 (JNU); Jeollanam-do: Damyang-gun, 30 Sep 2012, J. H. Kim 12115 (JNU); Sinan-gun, 8 Sep 2013, J. H. Kim 13068 (KH); Jeollabuk-do: Jinan-gun, 16 Sep 2012, J. H. Kim 12075 (JNU); Wanju-gun, 21 Sep 2012, J. H. Kim 12070 (JNU); Gochang-gun, 5 Sep 2012, J. H. Kim 12035 (JNU); Jangsu-gun, 27 Aug 2013, J. H. Kim 13029 (JNU); Jeongeup-si, 28 Sep 2013, J. H. Kim 13143 (JNU); Namwon-si, 26 Aug 2013, J. H. Kim $13024(\mathrm{JNU})$.

Fimbristylis pierotii Miq. 들하늘지기

KOREA. Gyeongsangnam-do: Hadong-gun, 13 Jul 2013, J. H. Kim 13060 (JNU); Jeollanam-do: Yeosu-si, 24 Jun 2009, H. T. Im 090139 (KB); Haenam-gun, 13 Jun 2010, H. D. Son Im 50646 (KB); Wando-gun, 29 Jun 2014, J. H. Kim 141204, J. H. Kim 141205, J. H. Kim 141207 (JNU); Sinan-gun, 31 Jul. 2011, J. H. Kim 187 (KB); 6 Jun 2007, J. H. Kim 739 (KB); 20 Jun 2015, J. H. Kim 152183 (JNU); 4 Jul 2015 , J. H. Kim 152216 (JNU).

Fimbristylis jindoensis J. Kim and M. Kim 진도하늘지기

KOREA. Jeollanam-do: Jindo-gun, 22 Jul 2014, J. H. Kim 141287, J. H. Kim 141288, J. H. Kim 141302, J. H. Kim 141305, J. H. Kim 141309, J. H. Kim 163583, J. H. Kim 163593, J. H. Kim 163596, J. H. Kim 163618, J. H. Kim 163623 (JNU).

Fimbristylis diphylloides Makino 검정 하늘지기

KOREA. Jeju-do: Jeju-si, 25 Sep 2014, J. H. Kim 141547 (JNU); Seogwipo-si, 19-21 Aug 2015, J. H. Kim 152351 (JNU); Jeollabuk-do: Jeongeup-si, 28 Sep 2013, J. H. Kim 13160 (JNU); Wanju-gun, 13 Sep 2013, J. H. Kim 13118 (JNU); Gochang-gun, 18 Sep 2015, J. H. Kim 152543 (JNU); Jeollanam-do: Gangjin-gun, 19 Aug 2012, J. H. Kim 12049 (JNU); Hwasun-gun, 3 Oct 2012, J. H. Kim 12103 (JNU); Jindogun, 1 Sep 2013, J. H. Kim 13108 (JNU); Gurye-gun, 10 Aug 2013, J. H. Kim 13051 (JNU).

Fimbristylis drizae J. Kim and M. Kim 물하늘지기

KOREA. Jeollanam-do: Jindo-gun, 31 Aug 2013, J. H. Kim 13097 (JNU); Gangjin-gun, 19 Aug 2012, J. H. Kim 12044 (JNU); Jangseonggun, 24 Aug 2012, J. H. Kim 12057 (JNU); 13 Oct 2012, J. H. Kim 12128 (JNU); Hwasun-gun, 12 Sep 2015, J. H. Kim 152497, J. H. Kim 152498 (JNU); Jeollabuk-do: Jeongeup-si, 28 Sep 2013, J. H. Kim 13138, J. H. Kim 13158 (JNU); Gochang-gun, 18 Sep 2015, J. H. Kim 152545, J. H. Kim 152546 (JNU).

Fimbristylis exaltata (T. Koyama) Y. F. Deng 어른지기

KOREA. Gyeongsangnam-do: Geoje-si, 2 Sep 2012, J. H. Kim 12037 (JNU); Jeju-do: Jeju-si, 25 Sep 2014, J. H. Kim 141558 (JNU); Seogwipo-si, 19-21 Aug 2015, J. H. Kim 152349 (JNU); Jeollanam-do: Sinan-gun, 9 Sep 2012, J. H. Kim 12005 (JNU); 8 Sep 2013 , J. H. Kim 13070 (JNU); Hampyeong-gun, 9 Sep 2012, J. H. Kim 12016 (JNU); Haenam-gun, 19 Aug 2012, J. H. Kim 12053 (JNU); Jangheunggun, 1 Aug 2013, J. H. Kim 13004 (JNU); Jindo-gun, 31 Aug 2013, J. H. Kim 13041 (JNU); Jeollabuk-do: Gunsan-si, 26 Aug 2013 , J. H. $\operatorname{Kim} 13020(\mathrm{JNU})$.

Fimbristylis autumnalis (L.) Roem. and Schult. 애기하늘지기

KOREA. Gangwon-do: Wonju-si, 29 Sep 2016, J. H. Kim 163931 (JNU); Gyeongsangbuk-do: Gimcheon-si, 20 Sep 2015, J. H. Kim 152576 (JNU); Jeollanam-do: Hwasun-gun, 12 Sep 2015, J. H. Kim 152502 (JNU): 3 Oct 2012, J. H. Kim 12099 (JNU); Suncheon-si, 2 Oct 2012, J. H. Kim 12097 (JNU); Gangjin-gun, 19 Oct 2012, J. H. Kim 12121 (JNU); Damyang-gun, 20 Oct 2012, J. H. Kim 12113 (JNU); Jeollabuk-do: Jangsu-gun, 27 Aug 2013, J. H. Kim 13025 (JNU); 1 Sep 2013, J. H. Kim 13130 (JNU); Namwon-si, 26 Aug 2013, J. H. Kim 13031 (JNU). 